\title{
Interpretation of Flow Logs from Nevada Test Site Boreholes to Estimate Hydraulic Conductivity Using Numerical Simulations Constrained by Single-Well Aquifer Tests
}

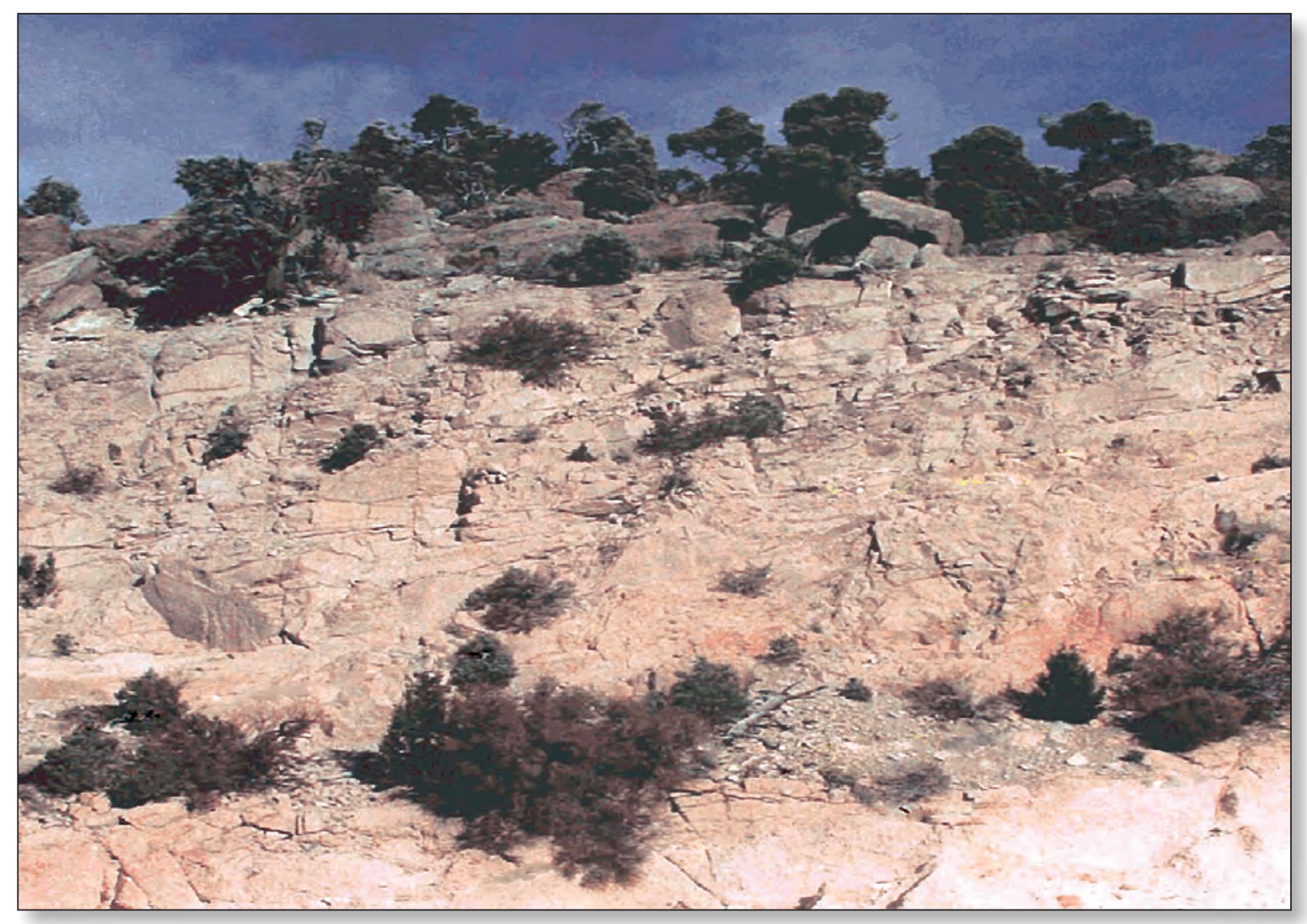

Scientific Investigations Report 2010-5004 
Cover: Photograph of Rainier Mesa, Nevada Test Site (Photograph taken by Randall J. Laczniak, U.S. Geological Survey, May 30, 2008.) 


\section{Interpretation of Flow Logs from Nevada Test Site Boreholes to Estimate Hydraulic Conductivity Using Numerical Simulations Constrained by Single-Well Aquifer Tests}

By C. Amanda Garcia, Keith J. Halford, and Randell J. Laczniak

Scientific Investigations Report 2010-5004 


\title{
U.S. Department of the Interior \\ KEN SALAZAR, Secretary \\ U.S. Geological Survey \\ Marcia K. McNutt, Director
}

\section{U.S. Geological Survey, Reston, Virginia: 2010}

\begin{abstract}
For more information on the USGS - the Federal source for science about the Earth, its natural and living resources, natural hazards, and the environment, visit http://www.usgs.gov or call 1-888-ASK-USGS

For an overview of USGS information products, including maps, imagery, and publications, visit http://www.usgs.gov/pubprod

To order this and other USGS information products, visit http://store.usgs.gov
\end{abstract}

\footnotetext{
Any use of trade, product, or firm names is for descriptive purposes only and does not imply endorsement by the U.S. Government.

Although this report is in the public domain, permission must be secured from the individual copyright owners to reproduce any copyrighted materials contained within this report.

Suggested citation:

Garcia, C.A., Halford, K.J., and Laczniak, R.J., 2010, Interpretation of flow logs from Nevada Test Site boreholes to estimate hydraulic conductivity using numerical simulations constrained by single-well aquifer tests: U.S. Geological Survey Scientific Investigations Report 2010-5004, 28 p.
} 


\section{Contents}

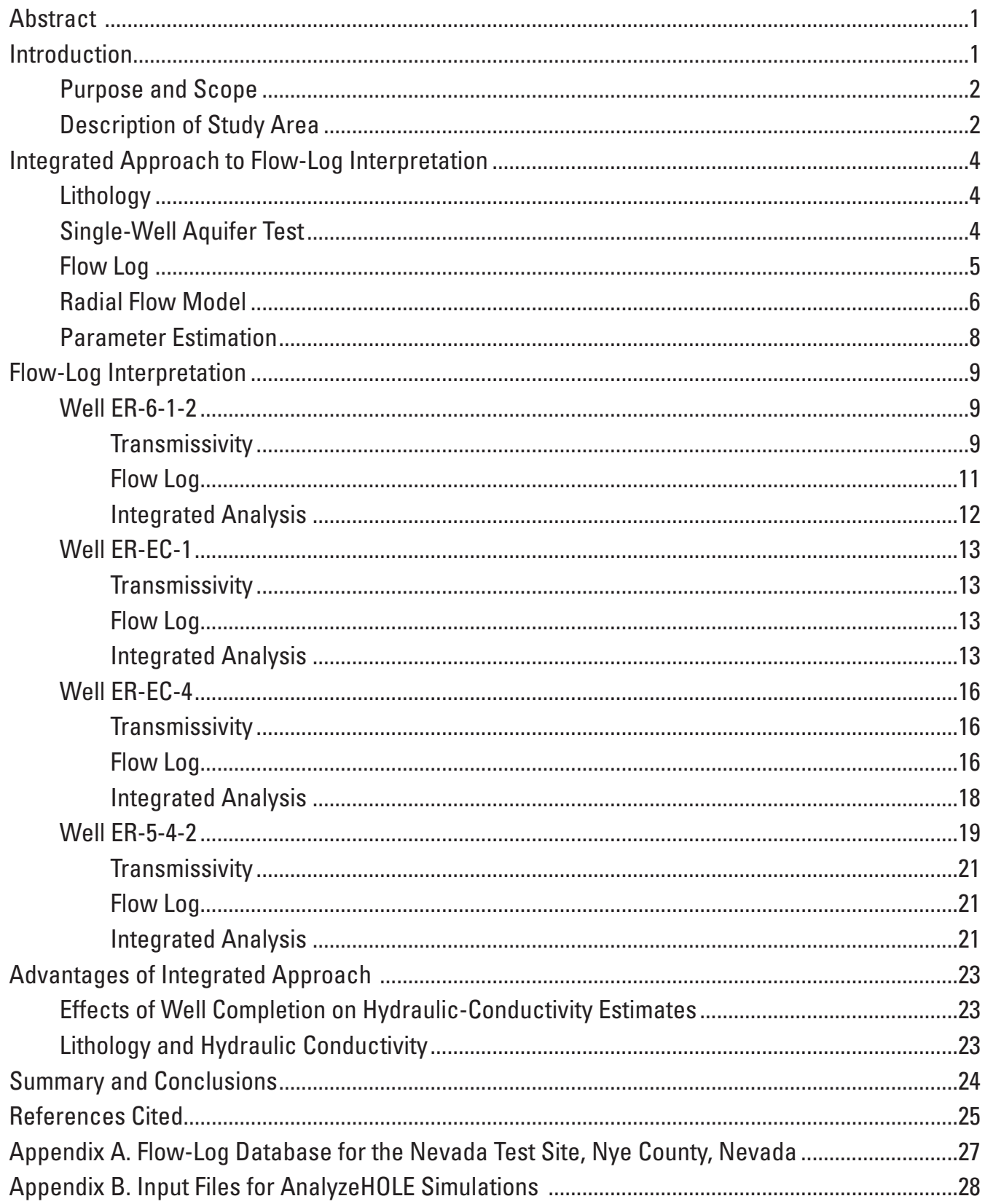




\section{Figures}

Figure 1. Map showing study area and location of wells analyzed, Nevada Test Site, Nevada

Figure 2. Graph showing periodic oscillations in a net-flow log measured in a cased section of well ER-EC-4, Pahute Mesa, Nevada

Figure 3. Graph showing original, interval-averaged, and polyline flow logs showing minimally contributing intervals from open borehole of well ER-6-1-2, Yucca Flat, Nevada

Figure 4. Graph showing model discretization used to simulate the wellbore, screen, and gravel pack.

Figure 5. Graphs showing well ER-6-1-2 well completion, lithologic log, polyline and simulated flow logs, and simulated hydraulic-conductivity distribution, Yucca Flat, Nevada

Figure 6. Graphs showing measured and synthetic water levels in well ER 6-1-2 and primary components used to construct synthetic water levels, Yucca Flat, Nevada

Figure 7. Graph showing comparison of simulated and measured flow-log discharge rates in borehole ER-6-1-2, Yucca Flat, Nevada

Figure 8. Graph showing well ER-EC-1 well completion, lithologic log, polyline and simulated flow logs, and simulated hydraulic-conductivity distribution, eastern Pahute Mesa, Nevada

Figure 9. Graph showing corrected water-level drawdown in well ER-EC-1, eastern Pahute Mesa, Nevada

Figure 10. Graph showing comparison of simulated and measured flow rates in borehole ER-EC-1, eastern Pahute Mesa, Nevada

Figure 11. Graph showing comparison of simulated and corrected drawdown after about 2 hours of pumping in borehole ER-EC-1, eastern Pahute Mesa, Nevada ....

Figure 12. Graphs showing well ER-EC-4 well completion, lithologic log, polyline and simulated flow logs, and simulated hydraulic-conductivity distribution, western Pahute Mesa, Nevada

Figure 13. Graph showing comparison of simulated and corrected drawdown after about 2 hours of pumping and the Cooper-Jacob fit in borehole ER-EC-4, western Pahute Mesa, Nevada

Figure 14. Graph showing comparison of simulated and measured flow rates in borehole ER-EC-4, western Pahute Mesa, Nevada

Figure 15. Graphs showing well ER-5-4-2 $(A)$ Well completion, $(B)$ lithologic log, $(C)$ polyline and simulated flow logs, and $(D)$ simulated hydraulic-conductivity distribution, Frenchman Flat, Nevada

Figure 16. Graph showing corrected drawdown during first 20 hours of pumping in borehole ER-5-4-2, Frenchman Flat, Nevada

Figure 17. Graph showing comparison of simulated and measured flow rates in borehole ER-5-4-2, Frenchman Flat, Nevada

Figure 18. Graph showing area simulated as contributing flow to well ER-5-4-2 during flow logging, Frenchman Flat, Nevada

Figure 19. Graph showing multiplicative standard deviation of hydraulic conductivity in contiguous intervals of dolomite or vuggy dolomite that occurred in well ER-6-1-2, Yucca Flat, Nevada 


\section{Tables}

Table 1. Input properties and discretization of wells evaluated with AnalyzeHOLE, Nevada Test Site, Nevada .............................................. 7

Table 2. Construction data and dominant lithology for wells evaluated with

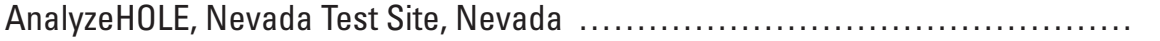

Table 3. Hydraulic conductivity estimated for lithologic units adjacent to borehole ER-6-1-2, Yucca Flat, Nevada

Table 4. Hydraulic conductivity estimated for lithologic units adjacent to screened intervals in borehole ER-EC-1, eastern Pahute Mesa, Nevada

Table 5. Hydraulic conductivity estimated for lithologic units adjacent to screened intervals in borehole ER-EC-4, western Pahute Mesa, Nevada....

\section{Conversion Factors, Datums, and Abbreviations and Acronyms}

Conversion Factors

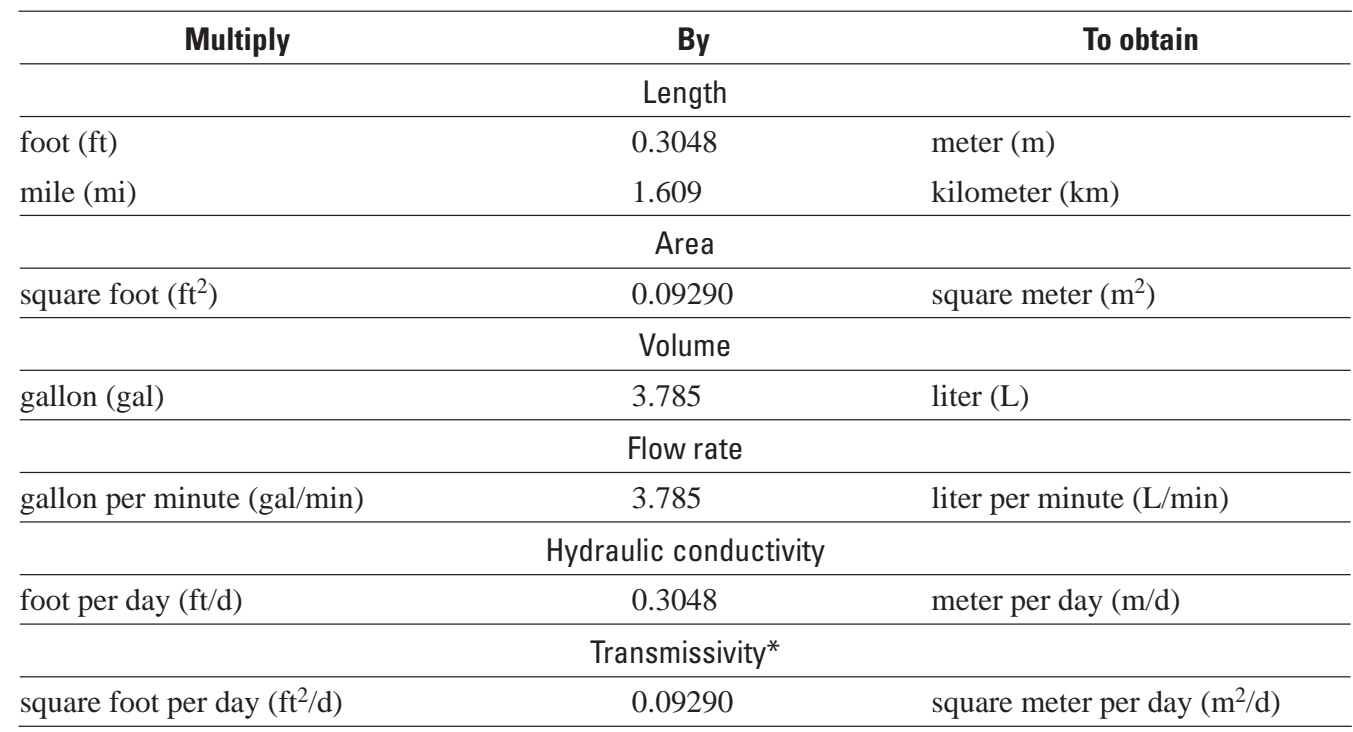

Temperature in degrees Fahrenheit $\left({ }^{\circ} \mathrm{F}\right)$ may be converted to degrees Celsius $\left({ }^{\circ} \mathrm{C}\right)$ as follows:

${ }^{\circ} \mathrm{C}=\left({ }^{\circ} \mathrm{F}-32\right) / 1.8$.

Elevation, as used in this report, refers to distance above the vertical datum.

*Transmissivity: The standard unit for transmissivity is cubic foot per day per square foot times foot of aquifer thickness $\left[\left(\mathrm{ft}^{3} / \mathrm{d}\right) / \mathrm{ft}^{2}\right] \mathrm{ft}$. In this report, the mathematically reduced form, square foot per day $\left(\mathrm{ft}^{2} / \mathrm{d}\right)$, is used for convenience.

Specific conductance is given in microsiemens per centimeter at 25 degrees Celsius $(\mu \mathrm{S} / \mathrm{cm}$ at $\left.25^{\circ} \mathrm{C}\right)$.

Concentrations of chemical constituents in water are given either in milligrams per liter (mg/L) or micrograms per liter $(\mu \mathrm{g} / \mathrm{L})$. 


\section{Conversion Factors, Datums, and Abbreviations and Acronyms-Continued}

Datums

Vertical coordinate information is referenced to the North American Vertical Datum of 1988 (NAVD 88).

Horizontal coordinate information is referenced to the North American Datum of 1983 (NAD 83).

Abbreviations and Acronyms

\begin{tabular}{ll}
\hline $\begin{array}{c}\text { Abbreviation or } \\
\text { Acronym }\end{array}$ & \multicolumn{1}{c}{ Meaning } \\
\hline AnalyzeHOLE & $\begin{array}{c}\text { Integrated wellbore analysis tool for simulating flow and transport in wells } \\
\text { and aquifer systems } \\
\text { (Mathematical FORmula TRANslating system) programming language } \\
\text { suited for numeric computation and scientific computing }\end{array}$ \\
FORTRAN & MODular finite-difference groundwater FLOW model \\
MODFLOW & Particle-tracking postprocessing model for MODFLW \\
MODPATH & Nevada Test Site \\
NTS & Parameter ESTimation software \\
PEST & Root mean square \\
RMS & Underground Test Area \\
UGTA &
\end{tabular}




\title{
Interpretation of Flow Logs from Nevada Test Site Boreholes to Estimate Hydraulic Conductivity Using Numerical Simulations Constrained by Single-Well Aquifer Tests
}

\author{
By C. Amanda Garcia, Keith J. Halford, and Randell J. Laczniak
}

\section{Abstract}

Hydraulic conductivities of volcanic and carbonate lithologic units at the Nevada Test Site were estimated from flow logs and aquifer-test data. Borehole flow and drawdown were integrated and interpreted using a radial, axisymmetric flow model, AnalyzeHOLE. This integrated approach is used because complex well completions and heterogeneous aquifers and confining units produce vertical flow in the annular space and aquifers adjacent to the wellbore. AnalyzeHOLE simulates vertical flow, in addition to horizontal flow, which accounts for converging flow toward screen ends and diverging flow toward transmissive intervals. Simulated aquifers and confining units uniformly are subdivided by depth into intervals in which the hydraulic conductivity is estimated with the Parameter ESTimation (PEST) software. Between 50 and 150 hydraulic-conductivity parameters were estimated by minimizing weighted differences between simulated and measured flow and drawdown. Transmissivity estimates from single-well or multiple-well aquifer tests were used to constrain estimates of hydraulic conductivity. The distribution of hydraulic conductivity within each lithology had a minimum variance because estimates were constrained with Tikhonov regularization.

AnalyzeHOLE simulated hydraulic-conductivity estimates for lithologic units across screened and cased intervals are as much as 100 times less than those estimated using proportional flow-log analyses applied across screened intervals only. Smaller estimates of hydraulic conductivity for individual lithologic units are simulated because sections of the unit behind cased intervals of the wellbore are not assumed to be impermeable, and therefore, can contribute flow to the wellbore. Simulated hydraulic-conductivity estimates vary by more than three orders of magnitude across a lithologic unit, indicating a high degree of heterogeneity in volcanic and carbonate-rock units. The higher water transmitting potential of carbonate-rock units relative to volcanic-rock units is exemplified by the large difference in their estimated maximum hydraulic conductivity; 4,000 and 400 feet per day, respectively. Simulated minimum estimates of hydraulic conductivity are inexact and represent the lower detection limit of the method. Minimum thicknesses of lithologic intervals also were defined for comparing AnalyzeHOLE results to hydraulic properties in regional ground-water flow models.

\section{Introduction}

Understanding groundwater flow is critical to developing accurate predictions of radionuclide transport. Hydraulic conductivity is one of the primary hydraulic properties controlling groundwater flow, and thus, directly affects the accuracy of simulated flow directions and velocities. Because groundwater velocity is proportional to hydraulic conductivity for a given gradient, erroneous hydraulic conductivities will result in inaccurate predictions of contaminant transport.

Flow logs frequently are used to identify permeable intervals in a well by measuring changes in borehole fluid velocity as a function of depth. These velocity changes are assumed to reflect incremental changes in formation discharge. Flow logs from the Underground Test Area (UGTA) Project of the Department of Energy's Environmental Restoration Program for the Nevada Test Site (NTS) typically have been interpreted using a proportional approach, which assumes that changes in flow-log response are associated only with the formation directly adjacent to the screen (Oberlander and others, 2002; Oberlander and Russell, 2003). This approach, therefore, assumes that hydraulic conductivity of the unit adjacent to the screened interval is directly proportional to the measured change in flow and that steady-state flow is parallel through adjacent aquifers or confining units. The transient response in multi-aquifer flow systems can be analyzed with analytical methods, provided that the independent aquifers communicate only through a borehole (Paillet, 1998). These analytically based proportional methods assume that vertical redistribution of flow through aquifer and gravel pack is negligible. 
Many of the characterization wells drilled at the NTS are completed with alternating sections of screen and blank casing. These complex completions can significantly alter the expected relation between changes in fluid velocity and hydraulic conductivity by introducing vertical flow components associated with an open or a gravel packed annulus behind the blank casing. Depths associated with permeable intervals often are estimated erroneously where flow converges at joints between screen and blank casing. This is because flow contributed by the rock adjacent to the blank casing is redistributed vertically creating anomalous velocity increases at the top and (or) bottom of screened intervals (Bowman and others, 1997). Flow from rock above or below a screened interval also can increase velocities near the top and bottom of a screened interval in partially penetrating wells. Gravel packs that are less permeable than the adjacent formations can mask flow contributions by vertically redistributing borehole flow across an entire packed interval (Halford, 2000).

An integrated wellbore analysis tool for simulating flow and transport in wells and aquifer systems, AnalyzeHOLE (Halford, 2009), is an effective alternative for simulating and evaluating complex well-aquifer system interaction. In this analysis tool, the wellbore and adjacent aquifer system is simulated with an axisymmetric, radial geometry in a twodimensional MODFLOW model. AnalyzeHOLE simulates vertical flow, in addition to horizontal flow, which accounts for converging flow toward screen ends and diverging flow toward transmissive intervals. Hydraulic conductivities are distributed by depth and estimated with Parameter ESTimation (PEST) software (Doherty and Johnston, 2003; Doherty, 2005) by minimizing squared differences between simulated flow and drawdown and measured flow and drawdown. Hydraulic conductivity can vary within a lithology, but variations are limited with regularization. Transmissivity of the simulated system can be constrained by estimates determined from single-well aquifer tests. A Microsoft Excel ${ }^{\circledR}$ spreadsheet is used to interface the various components simulated with AnalyzeHOLE by creating model input files, executing MODFLOW, MODPATH, PEST, and supporting FORTRAN routines, and importing and graphically displaying pertinent results.

\section{Purpose and Scope}

This report interprets hydraulic-conductivity distributions with an integrated approach where differences between simulated and measured borehole flow rates, drawdowns, and transmissivity were minimized simultaneously. Flow in the aquifer system and wellbore was simulated with a radial, axisymmetric MODFLOW model. Variability in hydraulic-conductivity estimates within each lithology also was minimized. Results from the integrated approach were compared to previous hydraulic-conductivity estimates that were not corrected for effects from complex well completions in heterogeneous aquifer systems. Four wells completed in volcanic or carbonate rock are analyzed and discussed in the report. Limitations associated with the hydraulic-conductivity estimates are discussed and attributed to deficiencies associated with well construction, flow-log measurements, and aquifer-test results, or a combination thereof.

\section{Description of Study Area}

The study area spans the NTS and surrounding area and is generally defined as the area encompassing four characterization wells (ER-6-1-2, ER-EC-1, ER-EC-4, and ER-5-4-2) drilled by the U.S. Department of Energy to investigate concerns about the potential for radionuclide transport (fig. 1). Characterization wells were selected by location and differing construction and lithologic formations. As defined, the study area is in Nye County, Nevada. Historically, the NTS has been the primary continental location for testing nuclear devices. Most nuclear tests conducted on the NTS were detonated underground in Frenchman Flat, Yucca Flat, Pahute Mesa, Rainier Mesa, and Shoshone Mountain. Detailed hydrologic and geologic descriptions of the area are given in Blankennagel and Weir, (1973), Winograd and Thordarson (1975), Laczniak and others (1996) and Mankinen and others (1999).

The Yucca Flat and Frenchman Flat underground test areas are in topographically closed basins in the eastern part of the NTS (fig. 1). These basins are part of a groundwater flow system that discharges to a line of regional springs in the Ash Meadows area south of the study area (Laczniak and others, 1996). Yucca Flat and Frenchman Flat are composed of a thick sequence of Tertiary-age, air-fall and ash-flow tuff that is overlain by Quaternary-age alluvium and underlain at depth by Paleozoic-age carbonate rock. The Tertiary-age section consists of volcanic-rock aquifers made up of primarily welded tuffs, and volcanic-rock confining units made up of primarily bedded and zeolitic tuffs. The higher hydraulic conductivity of the welded-tuff aquifers is attributed to secondary permeability associated with local jointing and fracturing. The Paleozoic-age carbonate-rock section is overlain throughout most of Yucca and Frenchman Flats by the volcanic-rock confining unit and is made up of a thick assemblage of interbedded dolomite and limestone deposited between early Cambrian and late Middle Devonian time. 


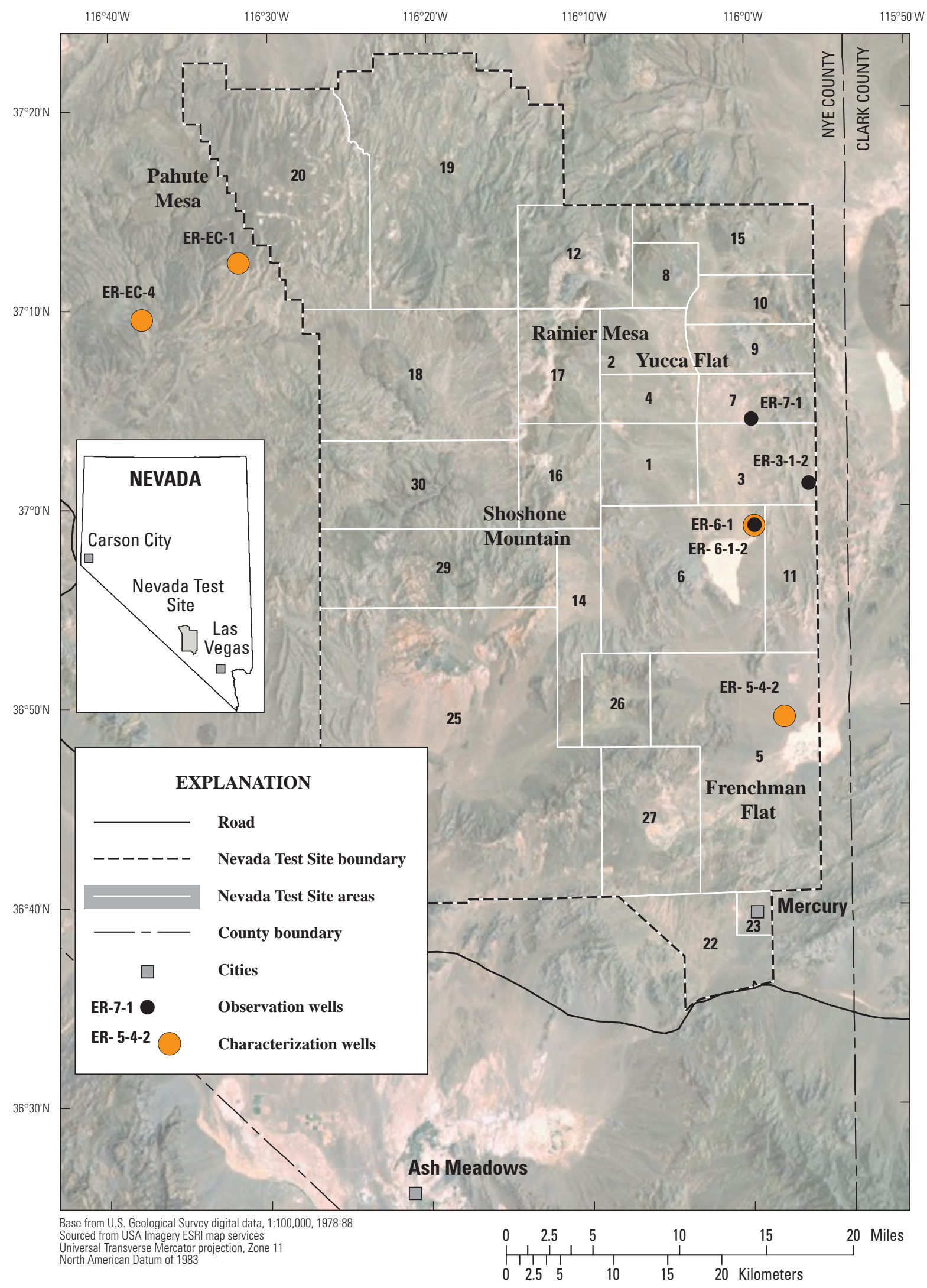

Figure 1. Study area and location of wells analyzed, Nevada Test Site, Nevada. 
This thick continuous block of carbonate rock forms the regionally extensive lower carbonate-rock aquifer. The high hydraulic conductivity of the carbonate-rock aquifer is attributed solely to secondary permeability associated with large-scale fracturing and some dissolution. Groundwater flow throughout the entire saturated section is locally controlled by major faults (Laczniak and others, 1996).

The Pahute Mesa underground test area is in eastern and central Pahute Mesa in the northwestern part of the NTS (fig. 1). Pahute Mesa is an extensive elevated plateau ranging in elevation from about 5,000 to 8,000 ft. Groundwater beneath Pahute Mesa generally flows southward but specific flow paths are uncertain. Some groundwater likely discharges to springs southwest of Pahute Mesa test area.

Pahute Mesa is underlain by a thick section of Tertiary-age rock deposited by multiple volcanic eruptions from several local calderas. These series of eruptions produced a complex assemblage of inter-bedded tuffs and lava flows that exceed 10,000 ft in thickness in the central part of the mesa. These tuffs and lava flows form the principal aquifers and confining units in the area. The principal aquifers are made up of extensive welded-tuff and lava-flow units, and the principal confining units are made up of non-welded and zeolitic bedded tuffs. The higher hydraulic conductivity of the welded-tuff and lava-flow aquifers is attributed to secondary permeability associated with local jointing and fracturing. Lava flows generally have the highest permeability but often have a more limited areal extent. Although welded tuffs are slightly less permeable than the lavas, the tuffs are more widespread and provide the primary pathways by which groundwater moves through the regional flow system (Mankinen and others, 1999). Groundwater flow throughout the saturated volcanic section is controlled locally by faults and by other low permeability geologic structures (Laczniak and others, 1996).

\section{Integrated Approach to Flow-Log Interpretation}

Flow logs are interpreted using a radial, axisymmetric flow model that simulates flow-log and drawdown response simultaneously under conditions consistent with the lithology, well construction, and an estimated transmissivity. Lithologic units are used as the primary indicator of hydraulic conductivity in the aquifer system because hydraulic conductivity frequently is assumed to be correlated with lithology. Transmissivity of the aquifer system and entry losses into the wellbore are defined from aquifer-test results. Flow logs are affected by hydraulic-conductivity contrasts between units which allow less permeable intervals to be differentiated from more permeable intervals along a vertical profile of a borehole. Lithologic descriptions, aquifer-test results, and flow logs are integrated into a single model so that all data sets can be evaluated simultaneously.

\section{Lithology}

Lithology often is used to identify and discriminate hydrogeologic units in boreholes at the NTS and to extrapolate those units across widespread areas having limited hydrologic data (Blankennagel and Weir, 1973; Winograd and Thordarson, 1975; Sweetkind and others, 2004; Bechtel Nevada, 2002, 2005). One of the basic premises behind the lithologic delineation of aquifers and confining units at the NTS is that fractured rock is inherently more permeable than non-fractured rock. Highly indurated rock units, such as lava flow, densely welded tuff, limestone, and dolomite, are assumed to fracture easily creating secondary permeability and porosity. The analysis in this report evaluates these basic concepts and uses the detailed lithology in drilling and well completion reports to group rock types in a borehole into discrete hydrogeologic units.

The lithology of rock units penetrated by boreholes drilled as part of the UGTA program is rigorously assessed and documented using cutting returns, and available geophysical logs and barrel and sidewall cores. This initial lithologic interpretation is documented in a preliminary drilling report. If necessary, the preliminary interpretation was modified based on a more thorough and integrated post-drilling analysis of all available information. The final detailed borehole lithology is documented in a final well-completion report. The preliminary and final lithologic descriptions were used in the analyses in this report to develop a consistent delineation of hydrogeologic units that best characterizes potential hydraulic-conductivity changes within a borehole. For some boreholes, detailed lithologic units that exhibited similar hydraulic properties, such as moderately welded with partially welded tuffs, were combined to reduce the number of units and to maintain a consistent hydrogeologic framework between boreholes. The section of borehole analyzed for this study typically extends from the top of the uppermost blank/screen interval to the base of the drilled borehole, and is assumed to represent the effective aquifer thickness.

\section{Single-Well Aquifer Test}

Single-well aquifer test results constrain hydraulic-conductivity estimates by defining the transmissivity of the aquifer system (Halford and others, 2006). Most transmissivity estimates used in this analysis were estimated using the Cooper-Jacob method (Cooper and Jacob, 1946). Cooper-Jacob estimates are independent of most well losses because the method involves interpretation of the drawdown slope rather than the total drawdown. The Cooper-Jacob method typically estimates the true value of transmissivity within a factor of two when the transmissivity of a confined aquifer exceeds $300 \mathrm{ft}^{2} / \mathrm{d}$ (Halford and others, 2006). 
Drawdown typically is calculated as the decline in the measured water level from pre-pumped conditions. However, when water-level fluctuations from barometric pressure and temperature changes, and earth tides are substantial relative to the decline caused by pumping, these non-pumping responses were removed with synthetic water levels (Halford, 2006). Synthetic water-levels simulate local non-pumping stresses that cause fluctuations in the water level. Synthetic water levels are the summation of multiple time series such as barometric pressure, tidal potential, borehole temperature, and background water levels. Synthetic water levels are fit to measured water levels during periods unaffected by the aquifer-test pumping by adjusting the amplitudes and phases of the component time series. Drawdown is computed as the difference between the synthetic and measured water levels after about 15 to 30 minutes of pumping to ensure that entry head losses have stabilized (Halford and Yobbi, 2006).

The effects of rising temperatures on expansion of the water column during single-well aquifer tests can overshadow the actual water-level response within the aquifer and lead to substantial uncertainty when estimating transmissivity. Expansion of the water column was simulated in the synthetic water levels and used a time series of temperature near the water surface in the pumped well. Uncertainty in the expansion of the water column still persists because of temperature measurement at a single depth. Multi-depth temperature measurements would substantially reduce this uncertainty and improve estimates of actual drawdown.

\section{Flow Log}

Flow logs record measurements of fluid velocity made within a section of well or borehole under pumped and non-pumped conditions and often are used to identify the most productive contributing intervals. Abrupt changes in fluid velocity are associated with contrasts in the hydraulic conductivity that can be caused by changes in rock lithology, borehole diameter, well completion, or by head differences in the aquifer system. Fluid velocity measurements with impeller driven flowmeters also can be affected by surface discharge, line speed, turbulence, tool centralization, and borehole diameter (Keys, 1990). These effects represent measurement noise and should be minimized before interpreting hydraulic-conductivity contrasts from flow logs.

The effect of ambient borehole flow, where present, can be eliminated by differencing flow logs measured at two different pumping rates. Hydraulic-conductivity estimates determined from flow logs where ambient flow is significant and not removed are likely erroneous (Molz and others, 1989). Ambient flow in an unpumped well can be significant where head differences exist between transmissive intervals.
The difference between two flow logs pumped at different rates can be used to remove ambient, head-driven borehole effects. In this report, the differenced log is referred to as the "net-flow log" and is the flow log analyzed to estimate the hydraulic-conductivity distribution.

Turbulence, tool rotation, and inadequate centralization can create oscillations in fluid velocity measurements. These erroneous responses were removed by averaging the flow across a given depth interval (fig. 2). Measurements from the net-flow $\log$ were averaged for consecutive depth intervals over an entire borehole. Interval lengths of 5 and $10 \mathrm{ft}$ were considered adequate because most small-scale fluctuations were removed from the flow log while velocity changes caused by well construction and hydraulic-conductivity contrasts were retained.

Flow responses indicative of a physically impossible, negative hydraulic conductivity can result even after differencing and interval averaging. Hydraulic conductivity is inversely proportional to the slope of the flow-log response (Javandel and Witherspoon, 1969). Negative slopes can be a result of changes in discharge rate, borehole diameter, or trolling speed. Negative hydraulic conductivities will be computed if negative slopes in the flow log are not removed or are ignored in the analysis.

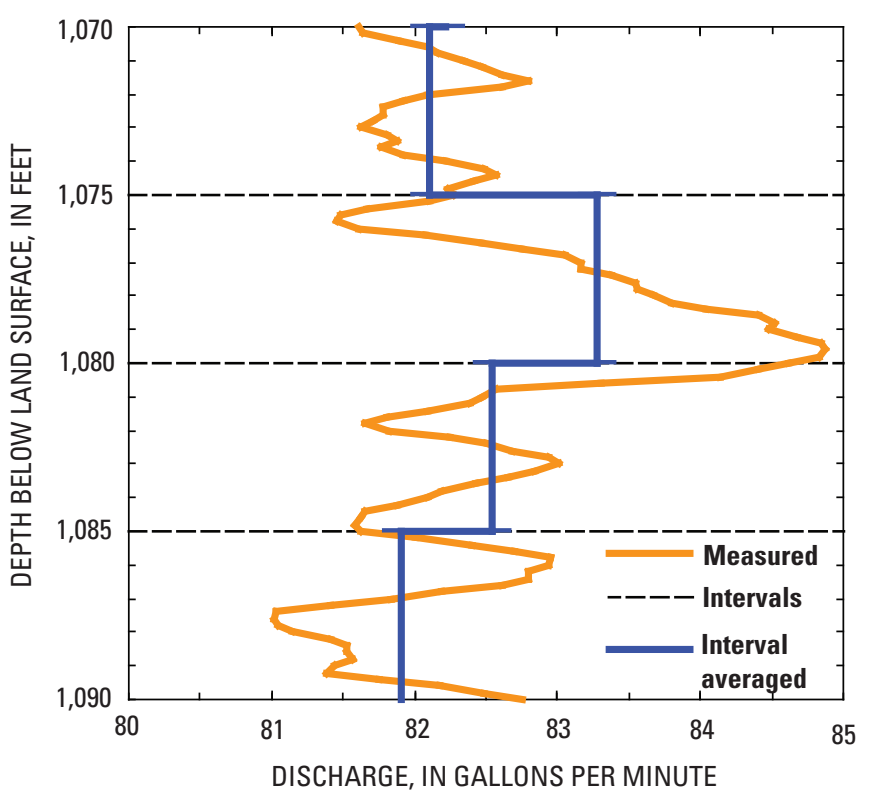

Figure 2. Periodic oscillations in a net-flow log measured in a cased section of well ER-EC-4, Pahute Mesa, Nevada. 
The integrated approach restricts flow changes to increases by approximating the net-flow log as a connected series of line segments collectively referred to as a polyline (fig. 3). A flow $\log$ is approximated with a polyline by sequentially adding line segments and minimizing the differences in the sum-of-square between the interval-averaged flow log and polyline. Line segments are added until all significant flow changes are captured and the sum-of-squares error ceases to significantly decrease with additional line segments. The constraint of a monotonic decrease with increasing depth excludes any possibility of computing a negative hydraulic conductivity. Flow logs typically can be approximated with a polyline that consists of less than two dozen segments and still maintain a monotonic decrease with depth and an infinite or positive slope (fig. 3). All increases in flow indicated by the polyline approximation are assumed to represent hydraulic-conductivity contrasts or well-construction effects. Additional points can be added along the polyline by linear interpolation to emphasize noncontributing intervals.

Vertical polyline segments (infinite slope) indicate an interval of negligible or minimal flow to the wellbore. These vertical segments are referred to as "minimally contributing intervals" (fig. 3). Cumulative flow increases of about 1 to 5 percent across these intervals could be added to the flow log without altering the overall interpretation (Moreo and others, 2003). The potential effect of this so-called ungaged flow was computed by uniformly distributing an increasing percentage ( 1 to 5 percent) of the total flow across all the minimally contributing intervals until a change in the flow distribution was observed.

\section{Radial Flow Model}

The adjacent aquifer system and pumping well are simulated with an axisymmetric, radial geometry in a one-layer MODFLOW model (McDonald and Harbaugh, 1988; Harbaugh and others, 2000), AnalyzeHOLE (Halford, 2009). Model input properties for each of the wells analyzed are given in table 1 and are referenced to the wellbore centroid (fig. 4). Radial distance increases with increasing column

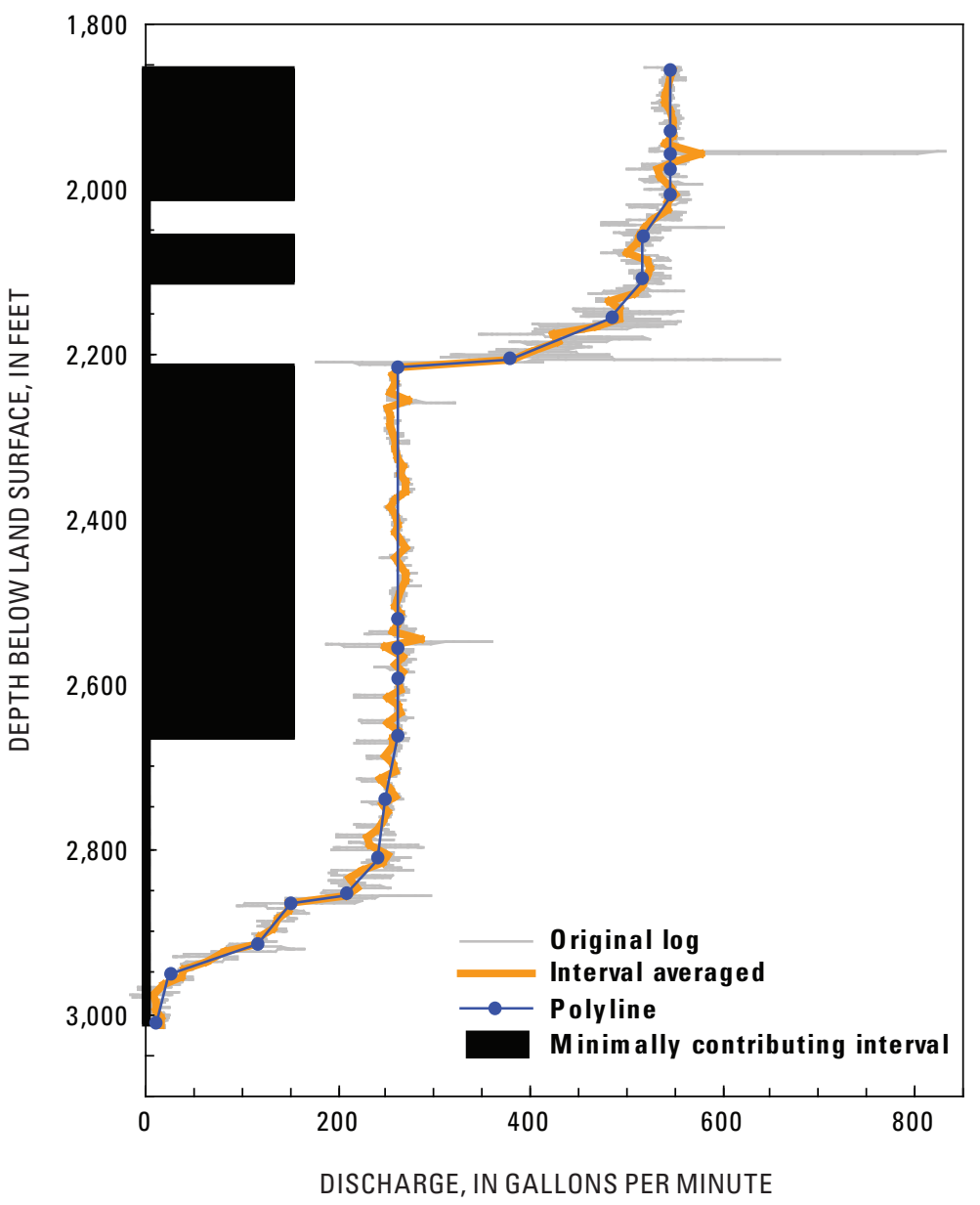

Figure 3. Original, interval-averaged, and polyline flow logs showing minimally contributing intervals from open borehole of well ER-6-1-2, Yucca Flat, Nevada.

indices (i) and depth increases with increasing row indices (j). Hydraulic conductivities and storage coefficients of the ith column are multiplied by $2 \pi r_{i}$ to simulate radial flow; where, $r_{i}$ is the distance from the outer edge of the first column to the center of the ith column. Numerous investigators have used MODFLOW to solve axisymmetric, radial flow problems by simulating a single row and multiple layers (Reilly and Harbaugh, 1993; Clemo, 2002). For convenience, AnalyzeHOLE uses only a single MODFLOW layer (Langevin, 2008). The use of a single layer allows for easily defined input, for all conductance values to be computed within the BCF package, and for output to be checked quickly. 
Table 1. Input properties and discretization of wells evaluated with AnalyzeHOLE, Nevada Test Site, Nevada.

[Annulus radius: Referenced to wellbore centroid. Abbreviations: in., inch; ft, foot; NA, not applicable]

\begin{tabular}{cccccccccccc}
\hline $\begin{array}{c}\text { Well } \\
\text { name }\end{array}$ & $\begin{array}{c}\text { Well } \\
\text { radius } \\
\text { (in.) }\end{array}$ & $\begin{array}{c}\text { Annulus } \\
\text { radius } \\
\text { (in.) }\end{array}$ & $\begin{array}{c}\text { Static water } \\
\text { level depth } \\
\text { (ft) }\end{array}$ & $\begin{array}{c}\text { Depth to } \\
\text { simulation } \\
\text { top } \\
\text { (ft) }\end{array}$ & $\begin{array}{c}\text { Depth to } \\
\text { simulation } \\
\text { base } \\
\text { (ft) }\end{array}$ & $\begin{array}{c}\text { Number } \\
\text { of } \\
\text { columns }\end{array}$ & $\begin{array}{c}\text { Number } \\
\text { of } \\
\text { rows }\end{array}$ & $\begin{array}{c}\text { Row } \\
\text { thickness } \\
\text { (ft) }\end{array}$ & $\begin{array}{c}\text { Simulated } \\
\text { period } \\
\text { (days) }\end{array}$ & $\begin{array}{c}\text { Specific } \\
\text { storage } \\
\text { (ft- }{ }^{-1} \text { ) }\end{array}$ & $\begin{array}{c}\text { Specific } \\
\text { vield }\end{array}$ \\
\hline ER-6-1-2 & 6.1 & NA & 1,545 & 1,800 & 3,200 & 54 & 100 & 14.00 & 1 & $2 \times 10^{-6}$ & NA \\
ER-EC-1 & 2.5 & 6.1 & 1,858 & 2,258 & 4,895 & 61 & 400 & 6.59 & 8 & $2 \times 10^{-6}$ & $2 \times 10^{-6}$ \\
ER-EC-4 & 2.5 & 6.7 & 750 & 952 & 3,487 & 55 & 319 & 7.95 & 5 & $2 \times 10^{-6}$ & 0.02 \\
ER-5-4-2 & 2.5 & 4.4 & 708 & 6,000 & 7,000 & 61 & 300 & 3.33 & 1 & $2 \times 10^{-6}$ & $2 \times 10^{-6}$ \\
\hline
\end{tabular}

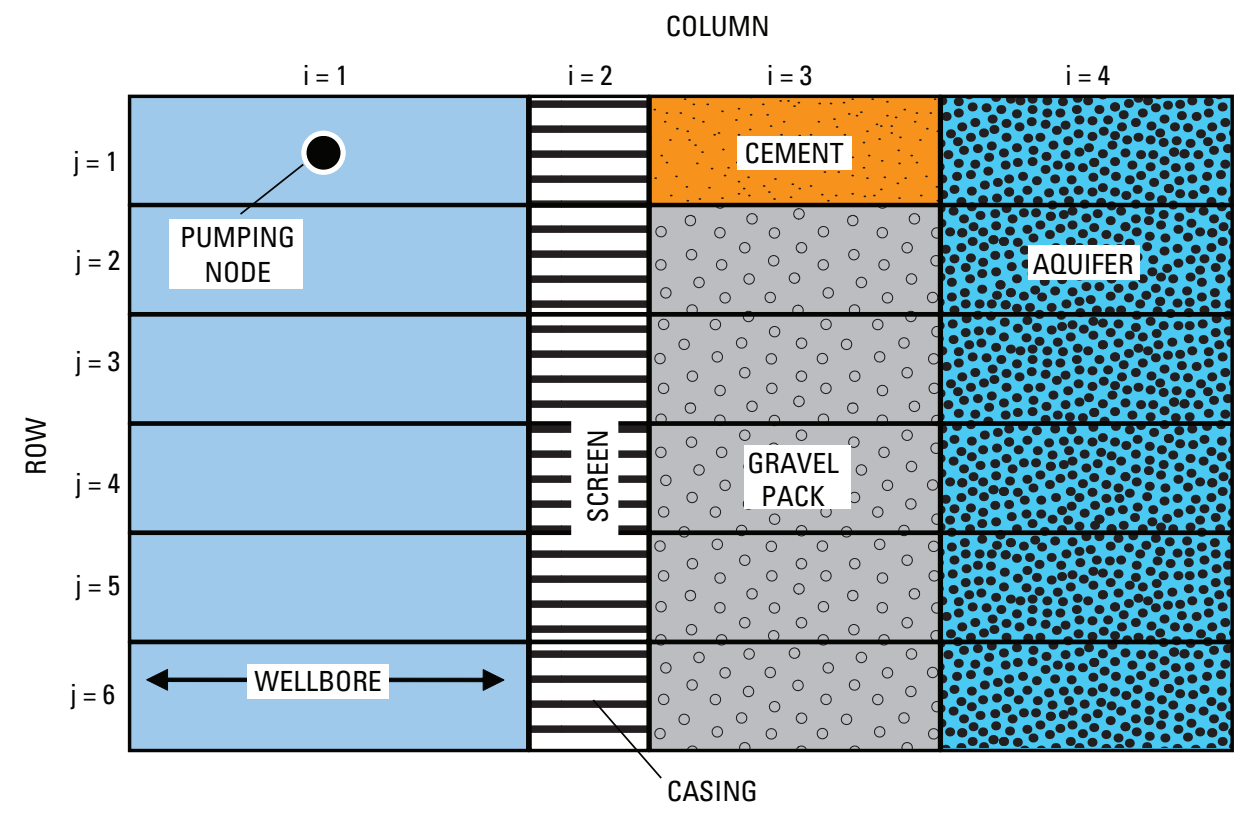

Figure 4. Model discretization used to simulate the wellbore, screen, and gravel pack.

The MODFLOW model domain is discretized uniformly with depth, which is simulated with rows. A uniform vertical discretization is used because the initial hydraulic-conductivity profile is unknown and any transient leakage from confining units is assumed to minimally affect the simulated flow log. The uppermost active row approximates the water table in unconfined aquifers and the contact between permeable aquifer and impermeable overlying confining unit in confined aquifers. The lower row represents the base of the aquifer system.
Column 1 simulates the wellbore radius where pumping is represented as turbulent pipe flow with an equivalent hydraulic conductivity (Halford, 2000; fig. 4). Equivalent hydraulic conductivities of wells with radii between 2 and $18 \mathrm{in}$. range between 0.03 and 30 billion ft/d, respectively. Typically, water is injected to simulate observed drawdown as positive heads. Water enters the uppermost node of the well and MODFLOW distributes flow to the remaining cells of the well (fig. 4). A single pumping rate is simulated during each stress period. 
Columns 2 and 3 are used to simulate well construction and annular fill, respectively (fig.4). Discretization and construction data for each well are given in tables 1 and 2 and appendix A. Casing and screens are simulated in column 2, where cased sections are represented by impermeable zones and screens are assigned the hydraulic conductivity of the adjacent gravel pack. Annular fill and gravel packs are simulated in column 3. Cemented annular fill is represented as an impermeable zone and gravel packs as intervals of different hydraulic conductivity. Effects of well construction, development, and encrustation on gravel packs can be represented by varying the hydraulic conductivity of the annular fill. Well losses are represented using the hydraulic conductivity of the annular fill rather than skin.

The aquifer system is simulated in columns 4 through $i$, where $i$ is inclusive of all columns representing the remaining radial extent of the model (fig. 4). A radial aquifer extent of 200,000 ft (referenced to the wellbore centroid) was assumed to represent an infinite system. Specific storage of the aquifer was assigned an assumed value for a compressible matrix (table 1). Heterogeneity within the aquifer system is represented by varying the hydraulic conductivity with depth and these varying hydraulic conductivities are represented by different lithologic classes and within class variations, but are assumed uniform in the radial direction. A single hydraulic conductivity is assigned initially to each unique lithologic class forcing a general uniformity between multiple occurrences of the same lithology.

Pumping rates simulated during the aquifer test and flow logging frequently differed because aquifer testing and flow logging did not occur simultaneously as part of well completion. The flow logs evaluated by AnalyzeHOLE represent the difference between two logs each pumped at a different rate. The pumping rate during the single-well aquifer test was specified so that the simulated and measured drawdown could be compared directly, and consequently the simulated flow log had to be scaled by the ratio of the flow-log and aquifer-test pumping rates (Halford, 2009).

\section{Parameter Estimation}

Horizontal hydraulic conductivities of the aquifer system and gravel pack are estimated by minimizing a composite, sum-of-squares objective function using PEST (Doherty, 2005). Vertical anisotropy is assigned an assumed value of 0.1. Hydraulic conductivities of the aquifer system are subdivided uniformly into 30 to 150 intervals with minor depth adjustments for screen-casing contacts and lithologic changes. Each of these intervals defines a laterally extensive unit of a uniform hydraulic conductivity which is estimated using PEST.
Table 2. Construction data and dominant lithology for wells evaluated with AnalyzeHOLE, Nevada Test Site, Nevada.

[C umulative length of screened interval: Excludes intermittent sections of blank casing. A bbreviation: ft, foot]

\begin{tabular}{|c|c|c|c|c|c|c|}
\hline \multirow[t]{2}{*}{$\begin{array}{l}\text { Well } \\
\text { name }\end{array}$} & $\begin{array}{c}\text { Altitude } \\
\text { (ft) }\end{array}$ & $\begin{array}{l}\text { Depth } \\
\text { drilled }\end{array}$ & $\begin{array}{l}\text { Depth } \\
\text { to top of } \\
\text { upper } \\
\text { screen }\end{array}$ & $\begin{array}{c}\text { Depth to } \\
\text { base of } \\
\text { lower } \\
\text { screen }\end{array}$ & $\begin{array}{c}\text { Cumulative } \\
\text { length of } \\
\text { screened } \\
\text { interval }\end{array}$ & \multirow[t]{2}{*}{$\begin{array}{l}\text { Dominant } \\
\text { lithology }\end{array}$} \\
\hline & \multicolumn{5}{|c|}{ (feet below land surface) } & \\
\hline ER-6-1-2 & 3,933 & 3,200 & ${ }^{1} 1,834$ & 13,200 & 1,365 & Dolomite \\
\hline ER-EC-1 & 6,026 & 5,000 & 2,297 & 4,749 & 630 & Lava and Tuff \\
\hline ER-EC-4 & 4,760 & 3,487 & 992 & 3,405 & 513 & Lava and Tuff \\
\hline ER-5-4-2 & 3,127 & 7,000 & 6,486 & 6,657 & 160 & Lava and Tuff \\
\hline
\end{tabular}

${ }^{1}$ Open hole.

Initial hydraulic conductivities are estimated from a polyline approximation of the net-flow log using the proportional approach (Javandel and Witherspoon, 1969). The proportional approach assumes that the borehole flow for a given depth interval $\left(\Delta Q_{i}\right)$ is proportional to the transmissivity of that interval $\left(T_{i}\right)$ :

where

$$
T_{i}=\alpha \Delta Q_{i},
$$

$\alpha$ is the dimensionless proportion constant.

The following equation can be used to compute a minimum (undetectable) hydraulic conductivity from the estimate of ungaged flow:

$$
K_{M I N}=\frac{Q_{U N}}{Q} \frac{T}{b_{M I N}},
$$

where

$Q_{U N}$ is the ungaged cumulative flow increase;

$Q$ is total discharge;

$T$ is the transmissivity of the aquifer system, and

$b_{\text {MIN }}$ is the total thickness of all minimally contributing intervals.

A cursory analysis indicates that the cumulative ungaged flow is typically about 1 percent; therefore, this value is assigned to each analyzed well. A maximum hydraulic conductivity of $500 \mathrm{ft} / \mathrm{d}$ is assigned to the gravel pack on the assumption that all packed intervals within a well completion are similar.

Observed and simulated borehole flow, drawdown, and transmissivity estimates are compared in the objective function (Halford, 2009). Borehole flow affects the relative magnitude of hydraulic-conductivity estimates. Drawdown constrains the overall head loss across the gravel pack and the later-time 
change in the drawdown constrains the transmissivity of the aquifer system. Simulated and measured drawdowns are compared at some time after pumping commences (typically 15 or 30 minutes) to ensure that entry head losses have stabilized (Halford and Yobbi, 2006). The addition of a transmissivity observation is redundant when sufficient drawdown data are available for the well being evaluated.

Borehole flow, drawdown, and transmissivity observations must be weighted by type so that all observation types influence hydraulic-conductivity estimates. Weighting is necessary because optimization routines do not consider differences in scale that are caused by different units or numbers of observations. For example, comparing simulated and measured drawdown in inches would cause drawdown observations to influence optimization results 144 times $\left(12^{2}\right)$ more than if drawdown had been compared in feet. Therefore, initial weights are scaled manually to ensure that the optimization process is influenced by all observation types. Observation weights are tracked by observation type in PEST and adjusted between optimization iterations to prevent a single observation type from dominating the parameter estimation process.

Regularization constrains hydraulic-conductivity distributions within similar lithologic units. Increased observations within a lithologic unit enforce the assumption that the hydraulic conductivity of each interval with the same lithology should be similar. Lithology is incorporated as an observation instead of a parameter allowing the hydraulic conductivity within a lithology to vary when dictated by measurements. This approach is a form of Tikhonov regularization which minimizes differences between parameters that minimally affect the objective function (Doherty and Johnston, 2003). Regularization also extrapolates estimates to cased intervals by minimizing the variability of hydraulic conductivity in a lithology and preserving the transmissivity of the aquifer system. Relative weighting between measurements and regularization observations are adjusted between optimization iterations in PEST (Doherty, 2005).

Minimum hydraulic-conductivity estimates are controlled by the sensitivity of flow-log measurements and are interpreted as a maximum possible. Simulated and measured flow logs will agree equally well with values equal to or less than these minimum hydraulic-conductivity estimates. Hydraulic-conductivity estimates less than this threshold minimally affect the simulated flow log and therefore are considered "censored" data. The minimum detection limit is an integrated estimate that depends on the observation types included in the simulation (for example, borehole flow and drawdown), relative weighting of each observation on the overall simulation, and variance of the total borehole hydraulic-conductivity distribution.

\section{Flow-Log Interpretation}

Flow logs were interpreted using a radial, axisymmetric flow model that simulates flow-log and drawdown response simultaneously to estimate the hydraulic conductivity of the different lithologies in a wellbore under conditions consistent with the lithology, well construction, and estimated transmissivity. Four wells, ER-6-1-2, ER-EC-1, ER-EC-4, and ER-5-4-2, were analyzed using the integrated approach.

\section{Well ER-6-1-2}

Well ER-6-1-2 is in southern Yucca Flat (fig. 1; U.S. Department of Energy, 2004) and is completed in carbonate rock. The well extends from a land-surface elevation of 3,933 ft to a depth of 3,200 ft. The depth to water measured December 14, 2002, was 1,546 ft. Well ER-6-1-2 is completed as open hole between the depths of 1,834 and 3,200 ft (table 2; appendix A). The well penetrates carbonate rock between the depths of 1,800 and 3,100 ft. This section of carbonate rock is bounded above by non-welded tuff and below by quartzite (appendix A). Dolomite comprises more than 90 percent of the lithologic section open to the wellbore (fig. 5). The section of the borehole analyzed with the model includes rocks between depths of 1,800 and 3,200 ft.

\section{Transmissivity}

The transmissivity of the carbonate-rock aquifer could not be estimated reliably from the single-well aquifer test because the water-level response and thermal expansion components were correlated inversely. Barometric and thermal changes exceeded drawdown in the aquifer for at least 3 days and negated the direct use of measured drawdown. Because significant contributing intervals were between 650 and 1,250 ft below the static water table, the maximum thermal expansion of the water column that could be estimated was $0.6 \mathrm{ft}$. Therefore, transmissivity was estimated indirectly by fitting synthetic water levels (Halford, 2006) to measured water levels. Aquifer response was simulated with a Theis model and an assumed storage coefficient of 0.0004 . Cumulative effects of pumping $160 \mathrm{gal} / \mathrm{min}$ between December 17, 2002, and December 23, 2002, and pumping $80 \mathrm{gal} / \mathrm{min}$ for 8 hours on January 3, 2003, were simulated by superposition. Transmissivity in the Theis model was estimated simultaneously to minimize differences between synthetic and measured water levels. Constructed synthetic water levels (Halford, 2006) fit measured water levels equally well assuming a transmissivity of 40,000 or $250,000 \mathrm{ft}^{2} / \mathrm{d}$ 

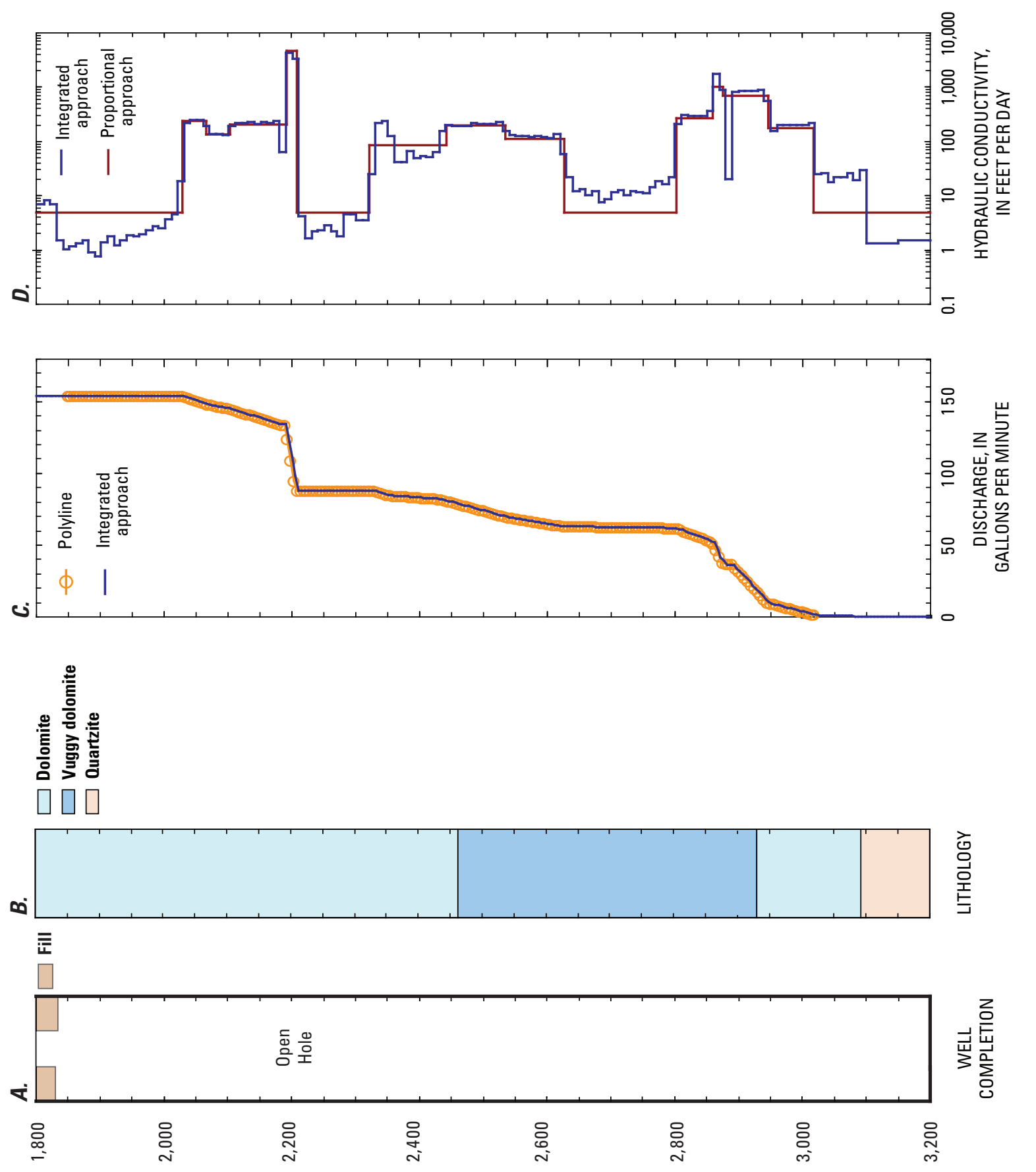

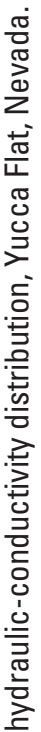

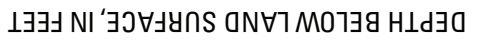


(fig. 6). Equal fits resulted because the estimated thermal expansion and well-entry losses compensated for differences in water-level response under the different scenarios of transmissivity. Measured water levels in well ER-6-1-2 could be matched equally well provided that the transmissivity of the carbonate-rock aquifer exceeded 30,000 $\mathrm{ft}^{2} / \mathrm{d}$.

The transmissivity of the carbonate-rock aquifer at ER-6-1-2 was estimated to be about $250,000 \mathrm{ft}^{2} / \mathrm{d}$ based on the results of a multi-well aquifer test (Stoller-Navarro Joint Venture, "ER-6-1 Well Cluster Multiple Well Aquifer Test-Tracer Test Data Report Volumes I, II, and III, written commun., 2005; Stoller-Navarro Joint Venture, “Analysis of Hydraulic Responses from the ER-6-1 Multiple-Well Aquifer Test, Yucca Flat FY 2004 Testing Program, Nevada Test Site, Nye County, Nevada," written commun., 2005). Well ER-6-1-2 was pumped at about $525 \mathrm{gal} / \mathrm{min}$ from April 24, 2004, to July 23, 2004. Drawdown was observed in wells ER-6-1, ER-3-1-2, and ER-7-1 (fig. 1). Well ER-7-1 is the farthest from well ER-6-1-2 at a distance of about $6 \mathrm{mi}$. The multi-well aquifer test could not be interpreted assuming radial symmetry because the drawdown measured in the various observation wells was not axisymmetric.

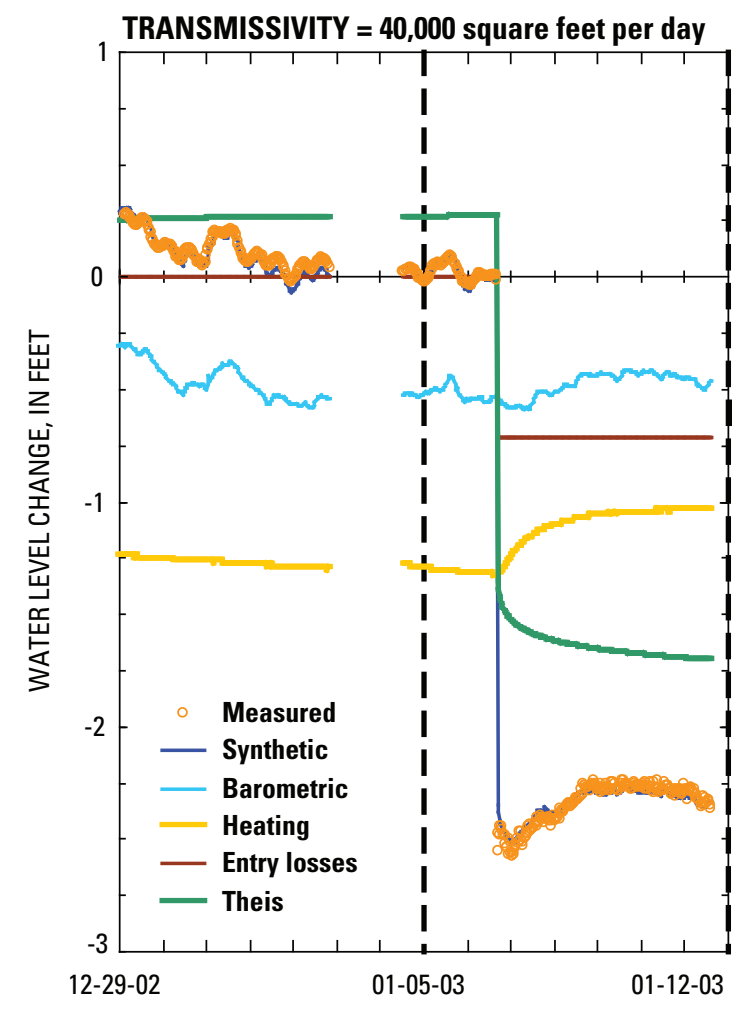

\section{Flow Log}

Flow was logged in well ER-6-1-2 between the depths of 1,850 and 3,120 ft at surface discharge rates of $0,275,427$, and $545 \mathrm{gal} / \mathrm{min}$ (Oberlander and Russell, 2003; appendix A). The response of the net-flow log determined by subtracting flow logs measured at discharge rates of 545 and $275 \mathrm{gal} / \mathrm{min}$ was generalized to a 16-point polyline. Additional points were interpolated every $5 \mathrm{ft}$ so that non-contributing intervals would influence parameter estimation (fig. 5C). A substantial increase in flow was recorded in all of the flow logs measured at about 2,200 and 2,900 ft. Increases at these depths along with numerous other flow increases noted on figure $5 C$ at various depths were recorded in both dolomite units. Lengthy sections of both dolomite units also contributed little if any detectable flow.

TRANSMISSIVITY $=$ 250,000 square feet per day

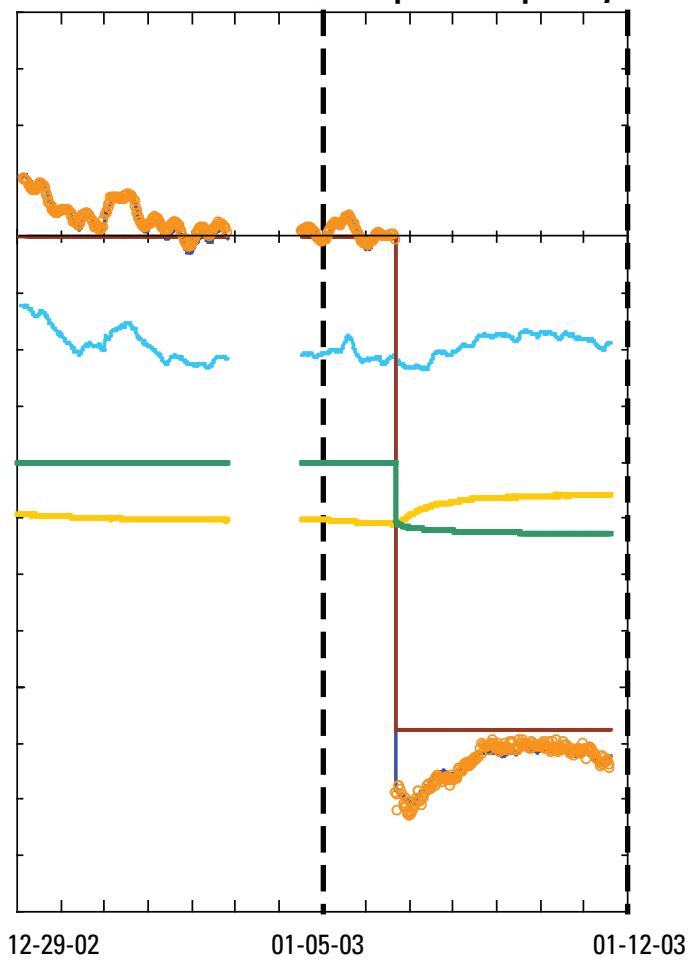

Figure 6. Measured and synthetic water levels in well ER 6-1-2 and primary components used to construct synthetic water levels, Yucca Flat, Nevada. 


\section{Integrated Analysis}

The radial flow model simulates a $1,300-\mathrm{ft}$ thick section of confined aquifer overlain by non-welded tuff and underlain by quartzite. The model simulates an open section of borehole that is divided into 133 intervals, each measuring about $10 \mathrm{ft}$. Initial hydraulic-conductivity estimates assigned to each depth interval averaged about $170 \mathrm{ft} / \mathrm{d}$ over the dolomite section and $220 \mathrm{ft} / \mathrm{d}$ over the vuggy dolomite section. Parameter estimation was weighted most heavily by flow-log discharge and the estimated transmissivity. Only a minimal weight was given to the drawdown because the effect of thermal expansion on the measured water-level response is uncertain.

Simulated flow reasonably matched measured flow with a root mean square (RMS) error of $0.3 \mathrm{gal} / \mathrm{min}$ (fig. 7). Small variations in the flow rate of less than $40 \mathrm{gal} / \mathrm{min}$ occurred within the transition zone between vuggy dolomite and dolomite.

Hydraulic conductivities in dolomite and vuggy dolomite reached maximum values of about 4,000 and $1,700 \mathrm{ft} / \mathrm{d}$, respectively (fig. $5 D$; table 3 ). However, the variation in the hydraulic-conductivity distribution simulated for each of the dolomite units spanned three orders of magnitude. High hydraulic-conductivity zones simulated within dolomite units are likely correlated with open fractures. The exclusion of these high flow intervals from summary statistics reduces the mean and multiplicative standard deviation by factors of 2 and 2 in dolomite, and 2 and 1 in vuggy dolomite, respectively. Hydraulic-conductivity estimates for the quartzite were below detection and represent less than 1 percent of the total borehole transmissivity.

Hydraulic-conductivity estimates derived from proportional and integrated approaches are similar as would be expected in an open-well completion (fig. 5D). The slight variations in the conductivities estimated across constant flow zones result from random noise inherent in both approaches. The primary difference between estimates of hydraulic conductivity is highlighted by comparing the minimum values, which are within the uncertainty of the method.

Table 3. Hydraulic conductivity estimated for lithologic units adjacent to borehole ER-6-1-2, Yucca Flat, Nevada.

[Standard deviation: Multiplicative standard deviation-the interval between $\mu \times \sigma^{2}$ and $\mu \div \sigma^{2}$ represents 95.5 percent of the log-normally distributed data. A bbreviations: $\mathrm{ft} / \mathrm{d}$, foot per day; $\mathrm{ft}$, foot; NA, not applicable, values are less than the detection limit of the method; <, less than]

\begin{tabular}{lcccccc}
\hline & & \multicolumn{3}{c}{ Hydraulic conductivity (ft/d) } & Percentage of \\
\cline { 3 - 6 } Lithology & $\begin{array}{c}\text { Thickness } \\
(\mathbf{f t})\end{array}$ & Maximum & Minimum & $\begin{array}{c}\text { Thickness } \\
\text { weighted mean } \\
(\boldsymbol{\mu})\end{array}$ & $\begin{array}{c}\text { Standard } \\
\text { deviation } \\
(\sigma)\end{array}$ & $\begin{array}{c}\text { total } \\
\text { transmissivity }\end{array}$ \\
\hline Dolomite & 820 & 4,000 & 1 & 170 & 20 & 54 \\
Vuggy dolomite & 480 & 1,700 & 7 & 240 & 7 & 46 \\
Quartzite & 100 & NA & NA & NA & NA & $<1$ \\
\hline
\end{tabular}




\section{Well ER-EC-1}

Well ER-EC-1 is in eastern Pahute Mesa (fig. 1) and is completed in volcanic rock (U.S. Department of Energy, 2000a). The well extends from a land-surface elevation of $6,026 \mathrm{ft}$ to a total depth of 5,000 ft. The measured depth to water in the well is about $1,858 \mathrm{ft}$. Well ER-EC-1 is completed with three intervals of alternating screen and blank casing between depths of about 2,297 and 4,749 ft (fig. 8A; appendix A). The dominant lithologic units include lava in the upper and lower screen intervals and bedded and partially welded tuff extending from the lower part of the upper screen section through the middle screen section (fig. 8B). Less common units include flow breccia, pumiceous and vitrophyric lava, and non-welded and vitrophyric tuff. With the exception of the non-welded tuff, a part of all lithologic units are intersected by one or more of the three screen intervals. The section of the borehole analyzed with the model includes rocks between 2,258 and 4,895 ft. This modeled interval includes the screen and blank casing adjacent to sand and gravel annular fill, and the gravel filled annulus extending more than $100 \mathrm{ft}$ below the well.

\section{Transmissivity}

A transmissivity of 7,000 $\mathrm{ft}^{2} / \mathrm{d}$ was estimated from the Cooper-Jacob method using drawdowns computed from water levels measured in well ER-EC-1 during a single-well aquifer test. Water levels, temperature, and discharge were monitored continuously 6 days prior to the test, during the test, and 5 days after the test (IT Corporation, "Western Pahute Mesa-Oasis Valley Well ER-EC-1 Data Report for Development and Hydraulic Testing," written commun., 2000). Pumping started January 19, 2000, and continued at a rate of about $120 \mathrm{gal} / \mathrm{min}$ for 7.5 days. The water level declined about $3 \mathrm{ft}$ after the first 7 hours of pumping and continued to decline another one-half foot by the end of the pumping period. Drawdown was computed by removing non-pumping and prior pumping effects from the waterlevel record using the approach documented by Halford (2006) and subsequently was filtered to reduce noise prior to model simulation. Synthetic water levels were corrected for barometric pressure, tidal effects, recovery from prior pumping, and thermal expansion of the water column $(0.5 \mathrm{ft})$ (fig. 9).

\section{Flow Log}

Flow was logged in well ER-EC-1 between depths of 2,250 and 4,640 ft at discharge rates of 0,64, 104, and $127 \mathrm{gal} / \mathrm{min}$ (Oberlander and others, 2002; appendix A). Depths recorded during flow logging were adjusted downward by $3 \mathrm{ft}$ to correct for measurement offset observed between measured discharge and blank/screen casing transition intervals. The response of net-flow log determined by subtracting flow logs measured at discharge rates of 127 and $64 \mathrm{gal} / \mathrm{min}$ was generalized to a 17-point polyline. An additional 38 points were added along the polyline by linear interpolation to emphasize non-contributing intervals (fig. 8C). The most substantial flow increases occur in the lava unit within the upper screen section at depths near 2,300 and 2,440 $\mathrm{ft}$ below land surface (fig. 8C). Intervals exhibiting the largest flow increases often are intermingled with zones of little or no flow. Flow within the borehole remains fairly constant at depths greater than $2,540 \mathrm{ft}$.

\section{Integrated Analysis}

The radial flow model simulates a 2,637-ft thick interval of confined aquifer overlain by non-welded tuff. The model includes cased and screened sections of the borehole that are divided into about 140 intervals each measuring about $20 \mathrm{ft}$. Intervals are categorized by lithology and discretized to be consistent with changes in the net-flow-log discharge with depth. Initial hydraulic-conductivity estimates assigned to each depth interval averaged 3 and $25 \mathrm{ft} / \mathrm{d}$ for flow breccia and lava, respectively, and 0.03 for pumiceous and vitrophyric lava, and bedded, non-welded, partially welded, and vitrophyric tuff. Equal weights were applied to discharge of net-flow log, estimated transmissivity, and measured drawdown for parameter estimation.

Simulated and measured flow rates closely matched with an RMS error of $0.5 \mathrm{gal} / \mathrm{min}$ (fig. 10). Most RMS error is attributed to minor differences between simulated and measured flow rates at the many screen/blank casing interfaces throughout each screened section.

Differences between simulated and measured drawdown were reasonable with an RMS error of $0.5 \mathrm{ft}$ (fig. 11). Most error is attributed to an overestimation of total transmissivity using the Cooper-Jacob method, which would explain a greater separation between measured and simulated drawdown with increasing time. 

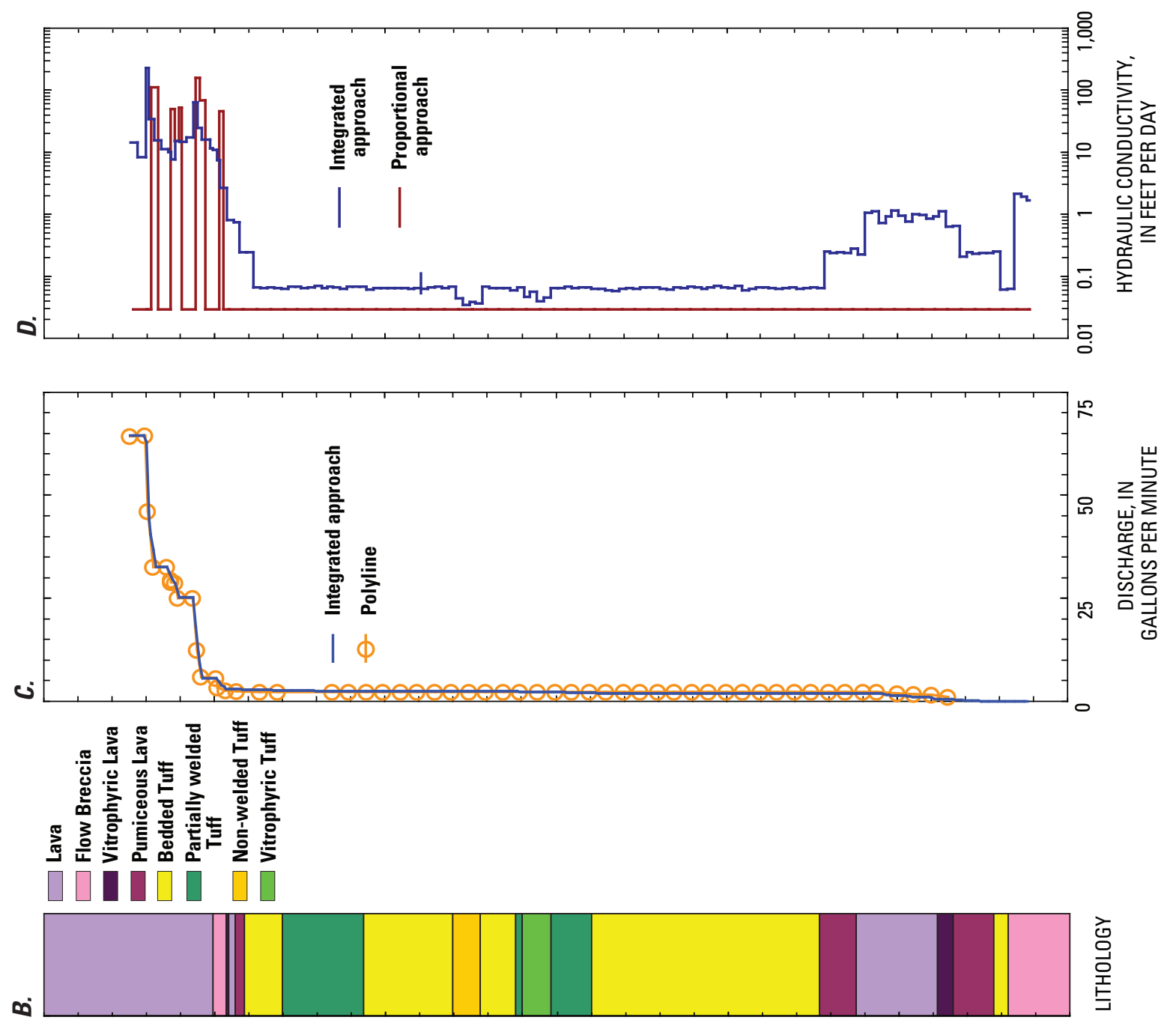

\section{言

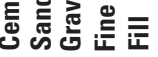

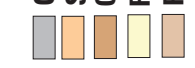

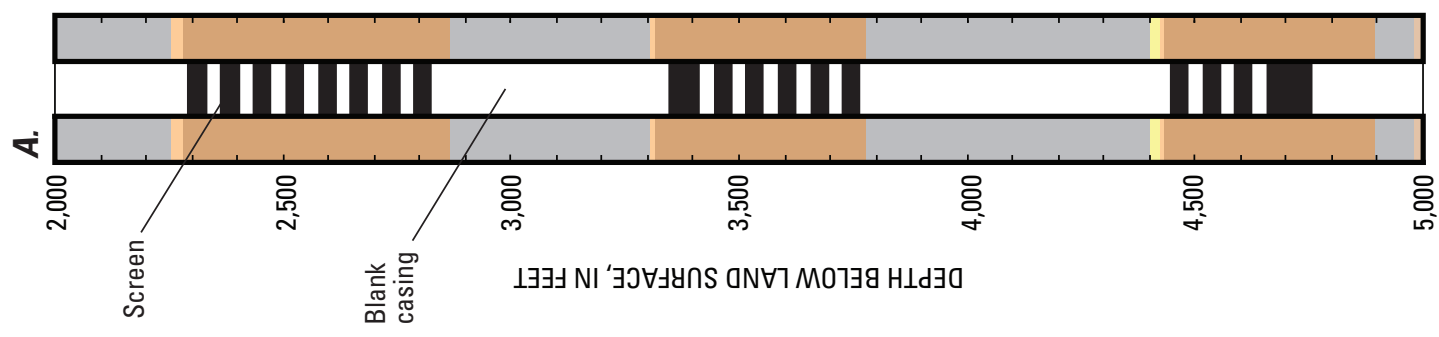




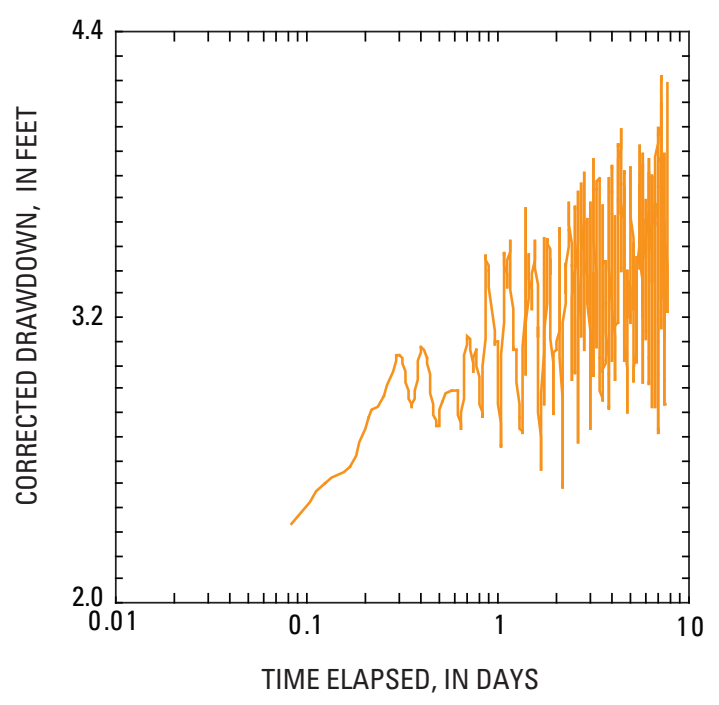

Figure 9. Corrected water-level drawdown in well ER-EC-1, eastern Pahute Mesa, Nevada.

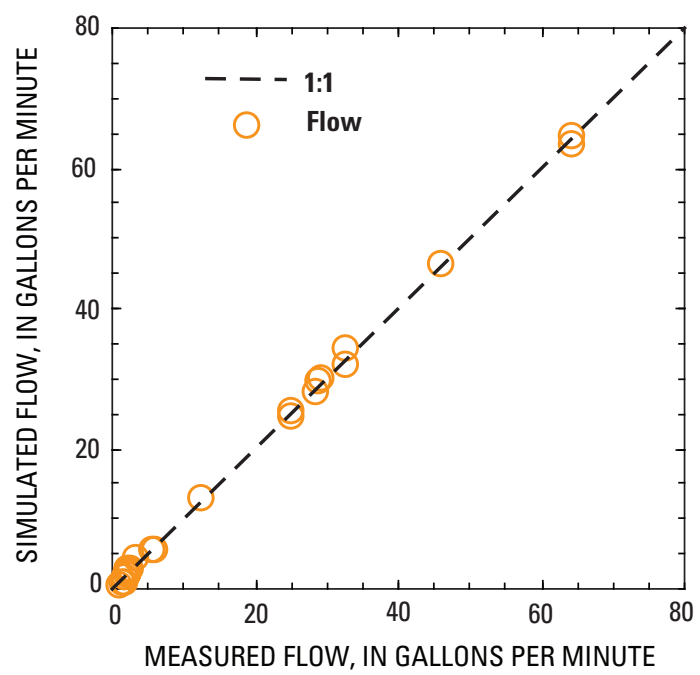

Figure 10. Comparison of simulated and measured flow rates in borehole ER-EC-1, eastern Pahute Mesa, Nevada.

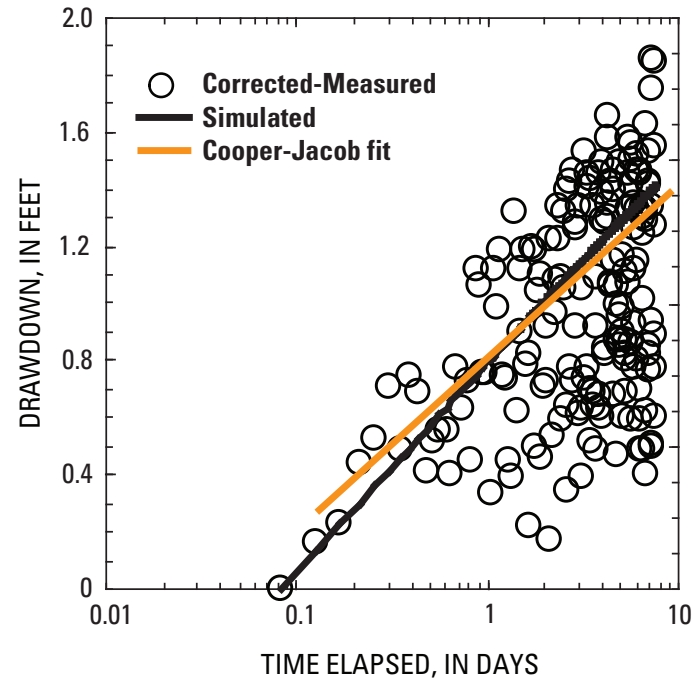

Figure 11. Comparison of simulated and corrected drawdown after about 2 hours of pumping in borehole ER-EC-1, eastern Pahute Mesa, Nevada.

Hydraulic-conductivity estimates are greatest for the lava and flow breccia lithologic units. Maximum values for these two units are 230 and $8 \mathrm{ft} / \mathrm{d}$, respectively (table 4; fig. 8D). The hydraulic-conductivity distribution within the lava unit varied by two orders of magnitude, indicating a high potential for vertical heterogeneity. Variance in the lava unit appears real with intermingled high and low flow zones behind alternating screen and blank casing (fig. 8D). The flow breccia distribution exhibited ambiguous homogeneity. Only 30 of the $180 \mathrm{ft}$ of simulated flow breccia are coincident with a screen interval, indicating that the hydraulic-conductivity distribution (figs. $8 B$ and $\underline{8 D}$ ) is mostly a projection and artifact of regularization. All other lithologic units were near the detection limit with thickness-weighted hydraulic conductivities estimated at or less than $1 \mathrm{ft} / \mathrm{d}$ (table 4).

Integrated and proportional hydraulic-conductivity estimates differed most in the lava unit (igs. $8 B$ and $\underline{8 D}$ ). The integrated approach distributes flow across the entire unit using the assumption that flow behind cased sections is converging within the screened section, whereas the proportional method attributes all flow logged in the associated units to screened sections only. Therefore, proportionally determined hydraulic-conductivity estimates are often greater than integrated estimates across screened sections and lower across blank casing. For example, in the upper screen section, integrated lava estimates are about 40 percent less, on average, than proportional estimates. Integrated and proportional approaches, however, attribute similar percentages of the total transmissivity to the lava units (91 percent). 
Table 4. Hydraulic conductivity estimated for lithologic units adjacent to screened intervals in borehole ER-EC-1, eastern Pahute Mesa, Nevada.

\begin{tabular}{|c|c|c|c|c|c|c|}
\hline \multirow[b]{2}{*}{ Lithology } & \multirow[b]{2}{*}{$\begin{array}{c}\text { Thickness } \\
\text { (ft) }\end{array}$} & \multicolumn{4}{|c|}{ Hydraulic conductivity (ft/d) } & \multirow{2}{*}{$\begin{array}{c}\text { Percentage } \\
\text { of total } \\
\text { transmissivity }\end{array}$} \\
\hline & & Maximum & Minimum & $\begin{array}{c}\text { Thickness } \\
\text { weighted mean } \\
(\mu)\end{array}$ & $\begin{array}{l}\text { Standard } \\
\text { deviation } \\
(\sigma) \\
\end{array}$ & \\
\hline Flow breccia & 30 & 8 & 3 & 4 & 2 & 6 \\
\hline Lava & 180 & 230 & 1 & 23 & 11 & 91 \\
\hline Pumiceous lava & 90 & .3 & $<.3$ & NA & NA & $<1$ \\
\hline Vitrophyric lava & 30 & .7 & $<.7$ & NA & NA & $<1$ \\
\hline Bedded tuff & 160 & .1 & $<.1$ & NA & NA & $<1$ \\
\hline Non-welded tuff & - & - & - & - & - & $<1$ \\
\hline Partially-welded tuff & 110 & .1 & $<.1$ & NA & NA & $<1$ \\
\hline Vitrophyric tuff & 30 & .1 & $<.1$ & NA & NA & $<1$ \\
\hline
\end{tabular}

\section{Well ER-EC-4}

Well ER-EC-4 is in western Pahute Mesa (ig. 1) and is completed in volcanic-rock (U.S. Department of Energy, 2000b). The well extends from a land-surface elevation of $4,760 \mathrm{ft}$ to a total depth of 3,447 ft. The measured depth to water is about $750 \mathrm{ft}$. Well ER-EC-4 is completed with three separate intervals of alternating screen and blank casing between about 992 and 3,405 ft (fig. 12A; appendix A). Screen is positioned in 30 - or $60-\mathrm{ft}$ intervals and blank casing in $40-\mathrm{ft}$ intervals. The dominant lithologic units include trachytic lava within and below the upper screen interval and partially welded tuff intersecting the middle and lower screen intervals (fig. 12B). Other lithologic units open to one or more of the screened intervals include bedded, vitrophyric, reworked, densely-welded, and non-welded tuffs. The section of the borehole analyzed with the model is defined by the depth interval between 952 and 3,467 ft. This interval includes all screens and blank casing adjacent to sand and gravel annular fill, and the open annular space extending $40 \mathrm{ft}$ below the well.

\section{Transmissivity}

A transmissivity of $50,000 \mathrm{ft}^{2} / \mathrm{d}$ was estimated from the Cooper-Jacob method using drawdown data computed from water levels measured in well ER-EC-4 during a singlewell aquifer test. Water levels, temperature, and discharge were monitored continuously 5 days prior to the test, during the test, and 6 days after the test (IT Corporation, "Western Pahute Mesa-Oasis Valley Well ER-EC-4 Data Report for Development and Hydraulic Testing," written commun.,
2000). Pumping started August 10, 2000, and was maintained at a rate of $182 \mathrm{gal} / \mathrm{min}$ for about 5 days, ceased for 16 hours, and began again at a rate of $182 \mathrm{gal} / \mathrm{min}$ for another 4 days. A water-level decline of about $1 \mathrm{ft}$ occurred after the first 2 hours of pumping and increased by $0.5 \mathrm{ft}$ over the next 5 days. Drawdown was computed by removing nonpumping and prior pumping effects from the water-level record using the approach documented by Halford (2006). Synthetic water levels also were corrected for thermal expansion of the water column (0.02 ft) during pumping (ig. 13). Transmissivity was estimated from drawdown responses measured after about 1 hour of pumping. Temperature of the water column minimally affected the transmissivity estimate.

\section{Flow Log}

Flow was logged in well ER-EC-4 between the depths of 932 and 3,392 ft at discharge rates of $0,61,123$, and $183 \mathrm{gal} / \mathrm{min}$ (Oberlander and others, 2002; appendix A). Depths recorded during flow logging were adjusted upward by $5 \mathrm{ft}$ to correct for measurement offset observed between measured discharge and the screen/blank casing transition intervals. The response of net-flow log determined by subtracting flow logs measured at discharge rates of 183 and $61 \mathrm{gal} / \mathrm{min}$ was generalized to a 36-point polyline (fig. 12C). Substantial flow increases predominantly are within the upper screen section between depths of 990 and 1,220 ft in the trachytic lava unit and are intermingled with sizable intervals of minimal or no flow. Only minor flow changes are recorded in the middle and lower screen sections at depths of about 2,100 and below 3,200 ft, respectively. 


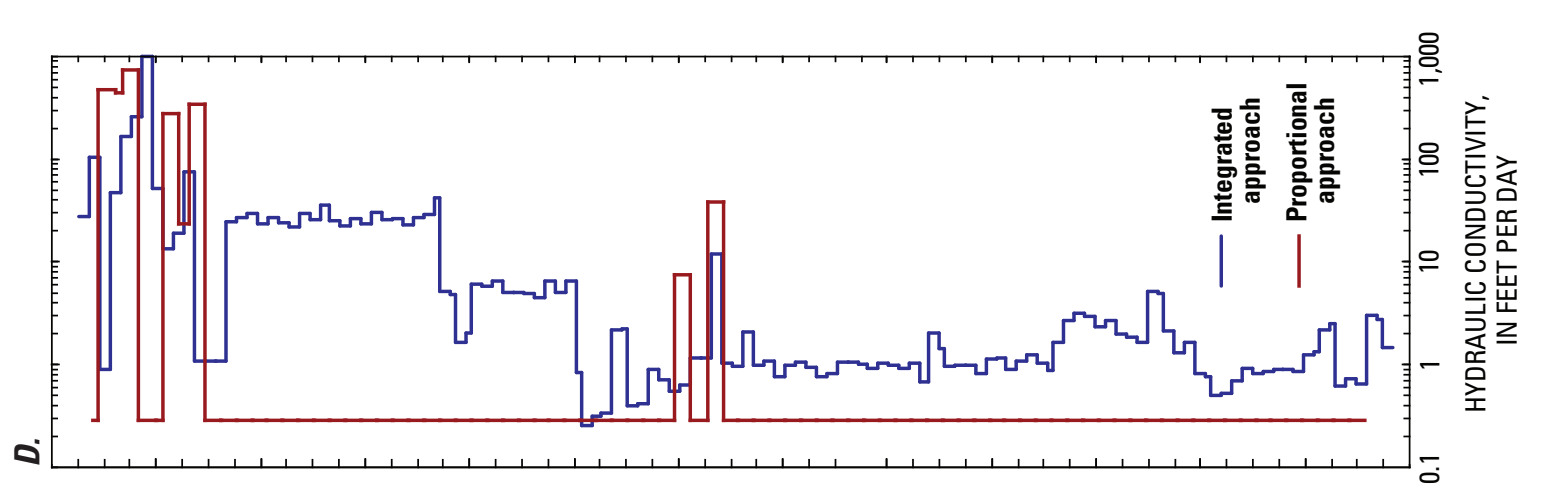

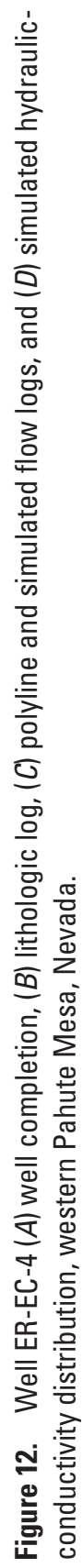

$\infty$
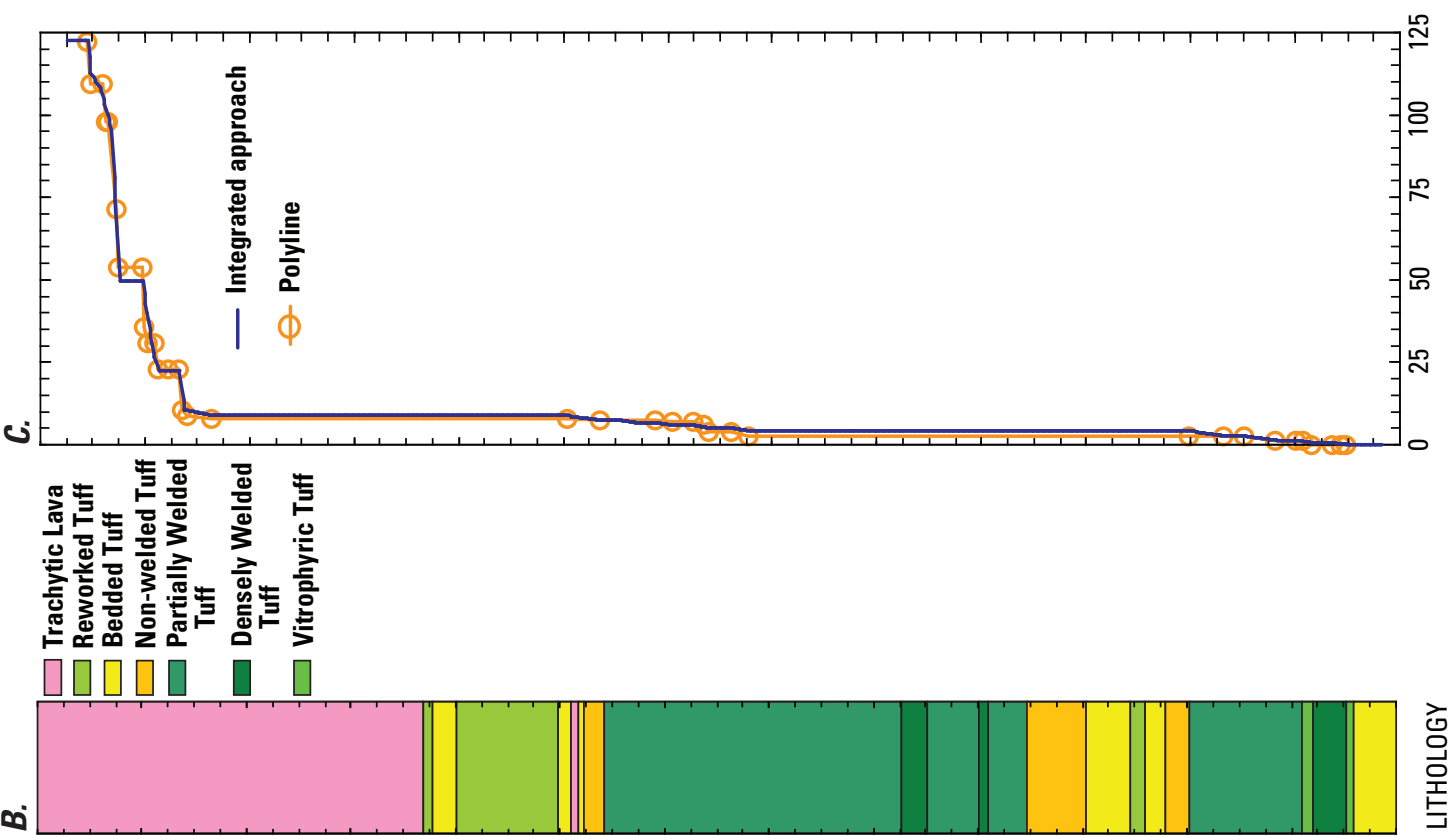

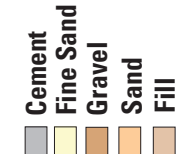
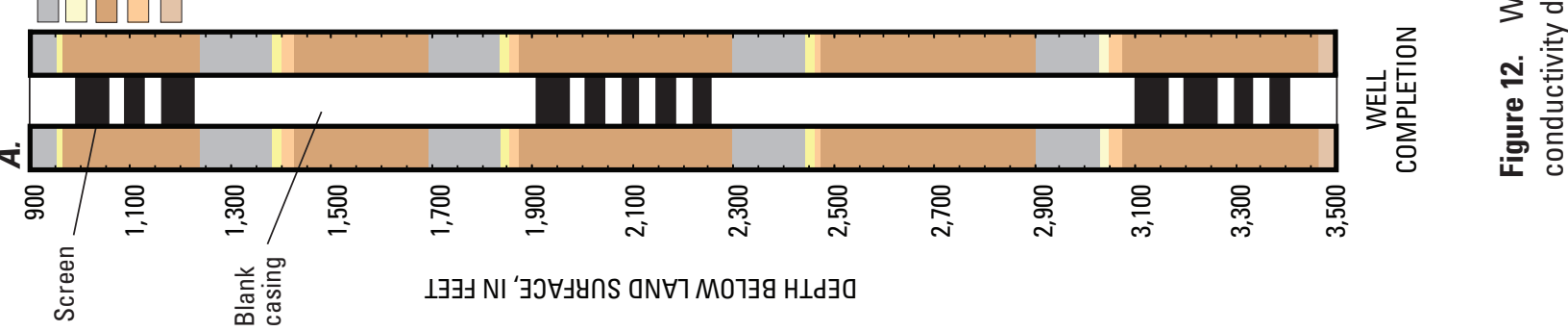


\section{Integrated Analysis}

The radial flow model simulates a 2,535-ft thick interval of confined aquifer overlain by non-welded tuff (fig. 12B). The model includes cased and screened sections of the borehole that are divided into about 130 intervals each measuring about $20 \mathrm{ft}$. Intervals are categorized by lithology and discretized to be consistent with changes in discharge with depth of the net-flow log. Initial hydraulic-conductivity estimates assigned to each depth interval averaged 90 and $3 \mathrm{ft} / \mathrm{d}$ for trachytic lava and partially-welded tuff, respectively, $2 \mathrm{ft} / \mathrm{d}$ for densely-welded tuff, and 0.01 for reworked, bedded, non-welded, and vitrophyric tuff. Equal weight was given to discharge of the net-flow log, estimated transmissivity, and measured drawdown for parameter estimation.

Simulated flow closely matched measured flow with an RMS error of $2.5 \mathrm{gal} / \mathrm{min}$ (fig. 14). The small error is attributed to minor offsets between the polyline and log-measured flow breaks and model discretization. The fit between simulated and corrected drawdown was good with a negligible RMS error of $0.1 \mathrm{ft}$ (fig. 13). The curvilinear drawdown simulated near the start of the aquifer test likely indicates a dual porosity response or a leaky boundary at or near the top of the upper casing that likely is associated with the overlying partially welded tuff.

The most permeable sections of the borehole occur within the upper screen interval adjacent to the trachytic lava lithologic unit. The lava unit represents 93 percent of the estimated borehole transmissivity and has a maximum estimated hydraulic conductivity of about 1,010 $\mathrm{ft} / \mathrm{d}$ (table 5). The hydraulic-conductivity distribution within the trachytic lava covers three orders of magnitude and indicates significant heterogeneity within the unit (table 5; fig. 12B and $\underline{12 D}$ ). Variability within this unit results from mixed zones of high and low permeability behind the screen and blank casing. Low permeability zones are apparent within upper screen section. Below the upper section of alternating screen and blank casing, hydraulic-conductivity estimates are largely a projection of regularization and reflect estimates from screened intervals.

Reworked and partially-welded tuff units coincident with the lower and middle screen intervals, respectively, were near the detection limit of the method (figs. 12B and $\underline{12 D}$ ). Any variance in the hydraulicconductivity distribution of the partially-welded and reworked tuffs was concealed by the analysis because minimums represent the detection limit of the method. In addition, only 2 percent of the $270 \mathrm{ft}$ of reworked tuff penetrated by the borehole was adjacent to a screened section of the wellbore. Hydraulic-conductivity estimates in bedded, non-welded, densely-welded, and vitrophyric tuffs also represent the detection limit of the method and are considered comparatively impermeable.

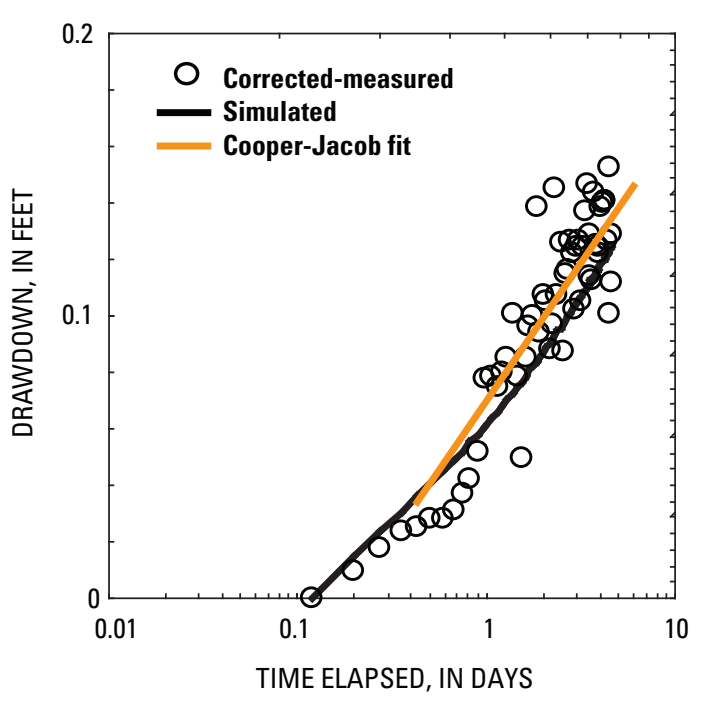

Figure 13. Comparison of simulated and corrected drawdown after about 2 hours of pumping and the Cooper-Jacob fit in borehole ER-EC-4, western Pahute Mesa, Nevada.

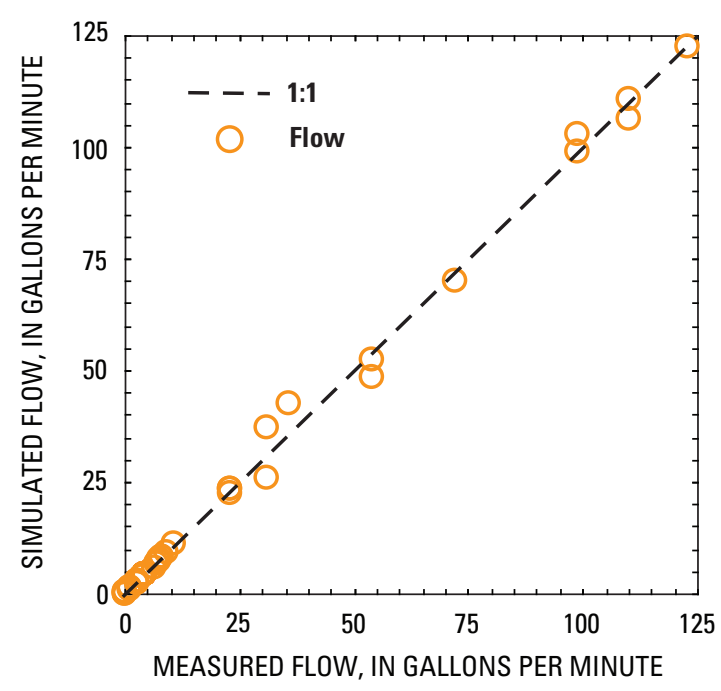

Figure 14. Comparison of simulated and measured flow rates in borehole ER-EC-4, western Pahute Mesa, Nevada. 
Table 5. Hydraulic conductivity estimated for lithologic units adjacent to screened intervals in borehole ER-EC-4, western Pahute Mesa, Nevada.

\begin{tabular}{|c|c|c|c|c|c|c|}
\hline \multirow[b]{2}{*}{ Lithology } & \multirow[b]{2}{*}{$\begin{array}{c}\text { Thickness } \\
\text { (ft) }\end{array}$} & \multicolumn{4}{|c|}{ Hydraulic conductivity (ft/d) } & \multirow[b]{2}{*}{$\begin{array}{c}\text { Percentage } \\
\text { of total } \\
\text { transmissivity }\end{array}$} \\
\hline & & Maximum & Minimum & $\begin{array}{c}\text { Thickness } \\
\text { weighted mean } \\
(\mu)\end{array}$ & $\begin{array}{c}\text { Standard } \\
\text { deviation } \\
(\sigma)\end{array}$ & \\
\hline Trachytic lava & 150 & 1,010 & 1 & 70 & 31 & 93 \\
\hline Bedded tuff & 50 & .5 & $<.5$ & NA & NA & $<1$ \\
\hline Densely welded tuff & 30 & 1 & $<1$ & NA & NA & $<1$ \\
\hline Non-welded tuff & 15 & 1 & $<1$ & NA & NA & $<1$ \\
\hline Partially welded tuff & 250 & 12 & $<1$ & NA & NA & 2 \\
\hline Reworked tuff & 6 & 1 & $<1$ & NA & NA & 3 \\
\hline Vitrophytic tuff & 4 & 2 & $<1$ & NA & NA & $<1$ \\
\hline
\end{tabular}

Hydraulic-conductivity estimates within the trachytic lava and partially-welded tuff derived using the proportional approach differed substantially from those determined with the integrated approach (figs. 12B and $\underline{12 D}$ ). Within the upper screen section, the thickness weighted mean of hydraulic conductivity in trachytic lava computed using the proportional approach (300 ft/d) is more than four times as great as the mean estimated by the integrated model $(67 \mathrm{ft} / \mathrm{d})$. Estimates from the integrated model were substantially lower because measured flow within the screened interval of trachytic lava was attributed to the effective thickness of the lithologic unit (adjacent to screened and blank casing) rather than the thickness of the screened interval only as was done with the proportional approach. Within the middle-screen section coincident with the partially-welded tuff, the thickness weighted mean from the proportional approach $(5 \mathrm{ft} / \mathrm{d})$ is twice the integrated estimate $(2.5 \mathrm{ft} / \mathrm{d})$. The proportional and integrated approaches attributed similar percentages of transmissivity to the trachytic lava, more than 92 percent, and partially-welded tuff units, less than 5 percent.

\section{Well ER-5-4-2}

Well ER-5-4-2 is in Frenchman Flat (fig. 1). The well extends from a land-surface elevation of $3,127 \mathrm{ft}$ to a total depth of 6,657 ft (U.S. Department of Energy, 2005). The measured depth to water on September 18, 2002, was $708 \mathrm{ft}$. Well completion consists of blank casing to about $6,486 \mathrm{ft}$ followed by $171-\mathrm{ft}$ interval of four alternating screens ( $40-\mathrm{ft}$ interval) separated by blank casing (fig. 15; appendix A). The annulus is open throughout the interval between 4,848 and $6,966 \mathrm{ft}$ and contains fill from 6,966 to 7,000 ft. Non-welded and bedded tuffs comprise about 60 and 30 percent, respectively, of the lithology between 6,000 and $7,000 \mathrm{ft}$. A thin 60 - $\mathrm{ft}$ layer of lava bounded above and below by nonwelded tuff is about $350 \mathrm{ft}$ above the interval of alternating screen and blank casing (fig. 15).

The section of the borehole analyzed with the model is defined by the depth interval between 6,000 and 7,000 ft. This interval extends upward about $500 \mathrm{ft}$ from the top of the uppermost screen and downward to the bottom of the hole. The upper limit was selected so that lithologic units adjacent to the open hole but above the screened interval were simulated. 

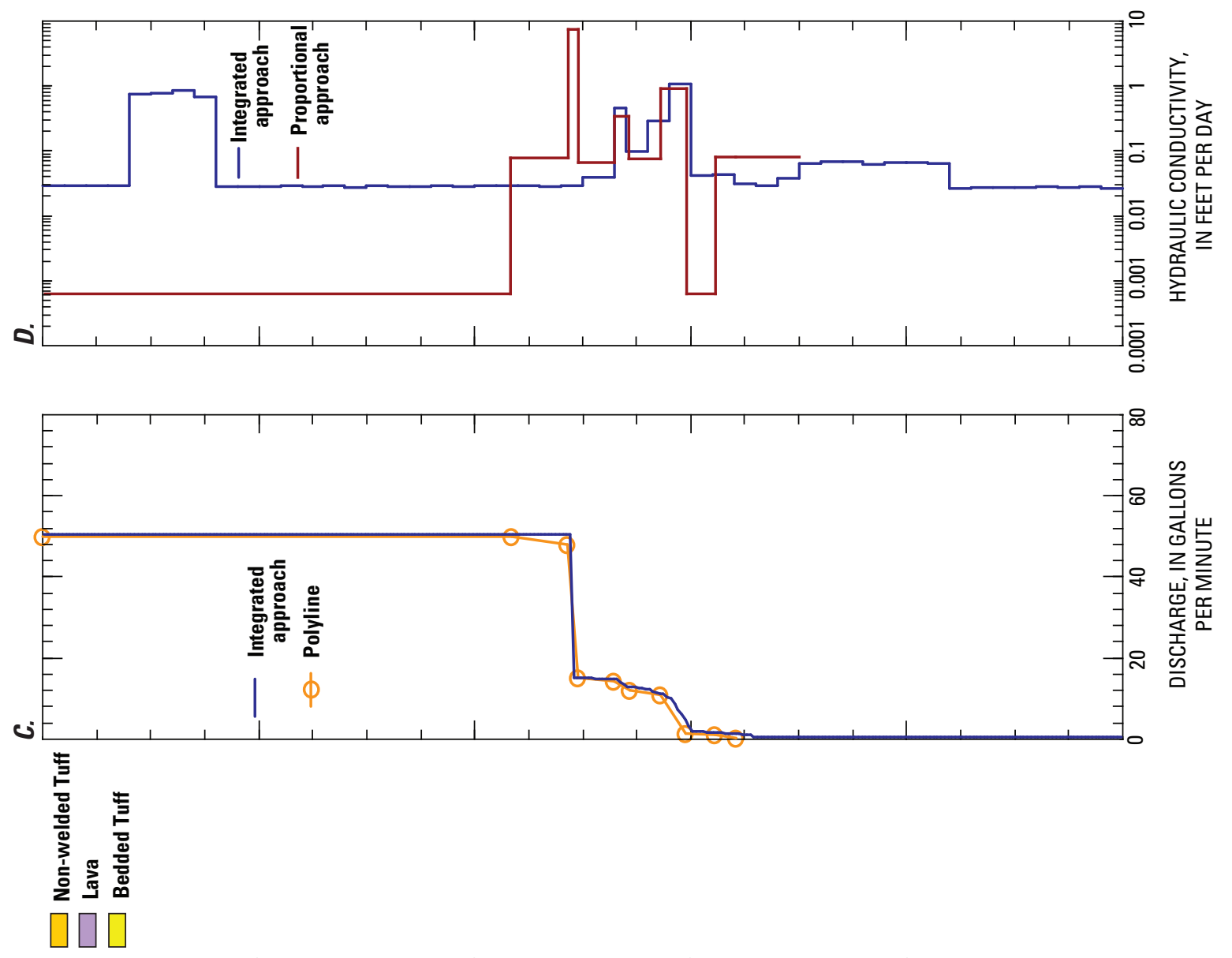

$\infty$
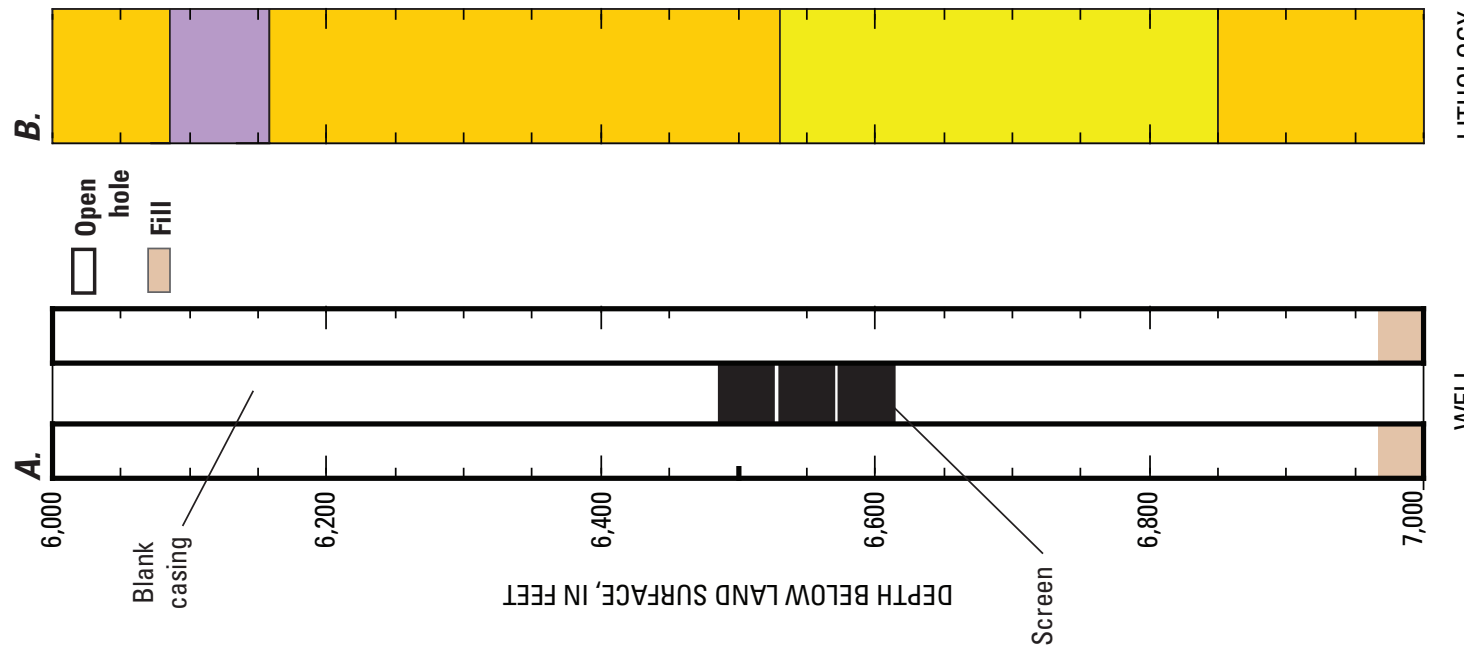

崫总

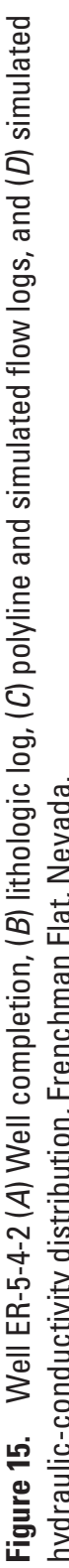




\section{Transmissivity}

A single-well aquifer test was conducted to estimate the transmissivity of the rock units open and adjacent to well ER-5-4-2 (Shaw Environmental Inc., "Frenchman Flat Well ER-5-4\#2 Data Report for Development and Hydrologic Testing" written commun., 2003). Water levels, temperature, and discharge were monitored continuously 6 days prior to the test, during the test, and 5 days after the test. Pumping started November 12, 2002, and continued at a rate of about $170 \mathrm{gal} / \mathrm{min}$ for one day, ceased for about 10 hours, resumed at a rate of $170 \mathrm{gal} / \mathrm{min}$ for 6 days, and then decreased as a step change to a rate of $125 \mathrm{gal} / \mathrm{min}$ for an additional 4 days. The water-level declined about $50 \mathrm{ft}$ after the first 7 hours of pumping and steadily decreased to a total decline of $130 \mathrm{ft}$ over the next 6 days. Drawdown was computed by removing nonpumping and prior pumping effects from the water-level record using the approach documented by Halford (2006). Synthetic water levels also were corrected for thermal expansion of the water column (90 ft) during pumping. Barometric pressure and tidal effects were insignificant compared to the large drawdown measured in the well. Temperature of the water column had a substantial effect on transmissivity, reducing the Cooper-Jacob estimate by about 40 percent.

The low-slope response of the corrected drawdown curve at the start of the aquifer test is indicative of wellbore storage (fig. 16). Because the water table is roughly $5,800 \mathrm{ft}$ above the first screened interval and the wellbore diameter increases from 5.5 to $9.6 \mathrm{in}$. at about $1,770 \mathrm{ft}$ above the first screened interval, the early drawdown response is assumed to be influenced by drainage from this larger-diameter, 4,000-ft length of wellbore.

A transmissivity of $110 \mathrm{ft}^{2} / \mathrm{d}$ was estimated by the Cooper-Jacob method from water-level measurements made in well ER-5-4-2 during the first day of the single-well aquifer test (fig. 16). An equivalent water-level response to aquifer pumping was simulated with a Theis (1935) model assuming a storage coefficient of 0.0002 .

\section{Flow Log}

Flow was logged in well ER-5-4-2 between the depths of 4,690 and 6,650 ft at discharge rates of 75, 125, and $175 \mathrm{gal} / \mathrm{min}$ (Oberlander and Russell, 2003; appendix A). Depths recorded during flow logging were adjusted upward by $4 \mathrm{ft}$ to correct for measurement offset observed between measured discharge and blank/screen casing transition intervals. The net-flow-log response determined by subtracting flow logs measured at discharge rates of 125 and $75 \mathrm{gal} /$ min was generalized to a 13-point polyline between depths of 6,000 and 7,000 ft (fig. 15C). Above the 6,000-ft depth,

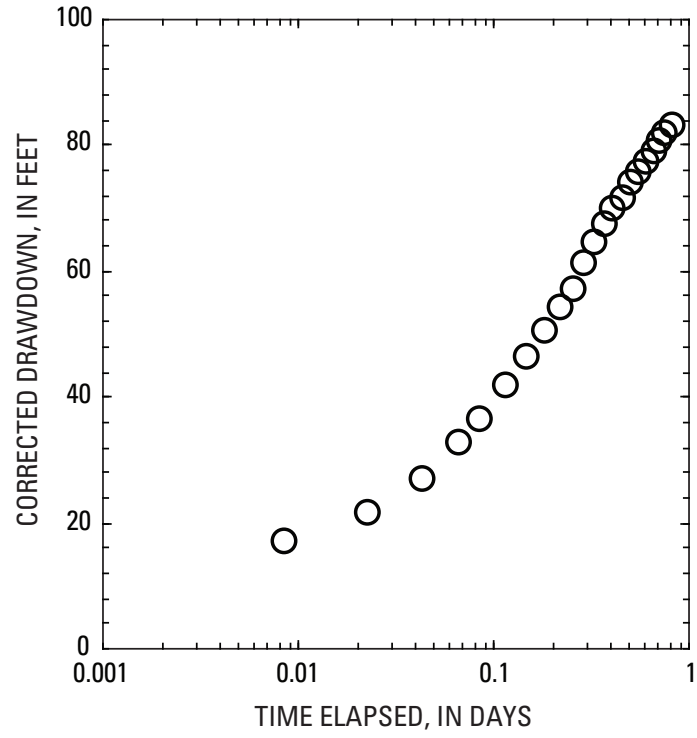

Figure 16. Corrected drawdown during first 20 hours of pumping in borehole ER-5-42, Frenchman Flat, Nevada.

the wellbore is cased. The only substantial increase in flow occurs at depths of about 6,490 and 6,570 ft (fig. 15C). These contributing intervals occur adjacent to non-welded and bedded tuff and are intermingled with intervals of minimal or no flow. The sharp increase in flow at the top of the screen is evidence of downward flow through the open annulus behind the blank casing in the upper part of the borehole.

\section{Integrated Analysis}

The radial flow model simulates a 1,000 -ft thick interval of confined material overlain by non-welded tuff. The model includes cased zones and a zone of alternating blank/screen casing. Zones are divided into 29 intervals each measuring about $40 \mathrm{ft}$. Intervals are categorized by lithology and discretized to be consistent with changes in the net-flow-log discharge with depth. Parameters used for model initialization represent the completion of the well, distribution of the lithologic units with depth, response of the net-flow log, the transmissivity estimate from the single well aquifer test, and initial estimates of the hydraulic conductivity determined from the proportional method. Heavier weight was given to the flow-log discharge and the estimated transmissivity. Drawdown measurements were not used in the parameter estimation process because early values were affected by annular drainage from the upper wellbore. 
The hydraulic-conductivity distribution estimated by parameter estimation and through regularization was non-unique. The non-uniqueness of the distribution is attributed to the well construction and completion design, primarily the $1,640 \mathrm{ft}$ of open, unpacked annulus above the screen interval. Simulated flow only generally matched measured flow with an RMS error of $3.2 \mathrm{gal} / \mathrm{min}$ (fig. 17).

The hydraulic-conductivity distribution estimated using the integrated approach indicates that the bulk of the measured flow enters the well through the lava unit that sits about $350 \mathrm{ft}$ above the top of the screened section of the wellbore (figs. 15B and $\underline{15 D}$ ). Contributions from this unit represent more than onehalf of the total transmissivity. Estimates, however, are highly uncertain because any one or a number of units within the nearly 1,650 - $\mathrm{ft}$ thick section of open hole above the top screen also could have contributed to the total borehole transmissivity.

Hydraulic-conductivity estimates derived using the proportional approach differed substantially from those simulated by the integrated approach. Because the proportional approach does not consider well completion, and therefore, ignores any vertical flow through 2,120 ft of open annulus in the borehole, all the transmissivity was attributed to the non-welded and bedded tuffs within the screened section.

As stated previously, hydraulic-conductivity estimates based on any flow-log analysis of well ER-5-4-2 are non-unique because of the design of the well completion, specifically the lengthy open section of annulus across from cased wellbore. Although the section of alternating screen and blank casing spans about $200 \mathrm{ft}$, the remaining 1,950 ft of open annulus behind the cased wellbore introduces unnecessary uncertainty in any estimates of hydraulic conductivity. Evidence for vertical flow-redistribution within the open annulus is shown in the results of the integrated analysis and shown in figure 18 where the lava unit, $350 \mathrm{ft}$ above the screened section, contributes a substantial amount of the measured flow to the wellbore. Results of the integrated analysis also indicate that about 15 percent of the total flow is contributed by the non-welded tuff unit, which also is above the screened section.

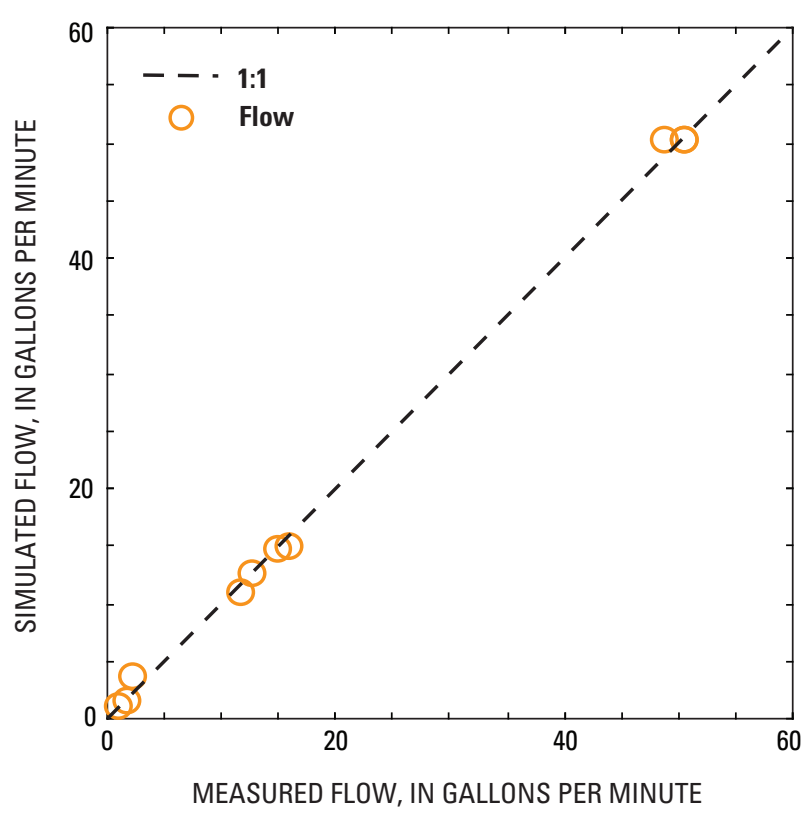

Figure 17. Comparison of simulated and measured flow rates in borehole ER-5-4-2, Frenchman Flat, Nevada.

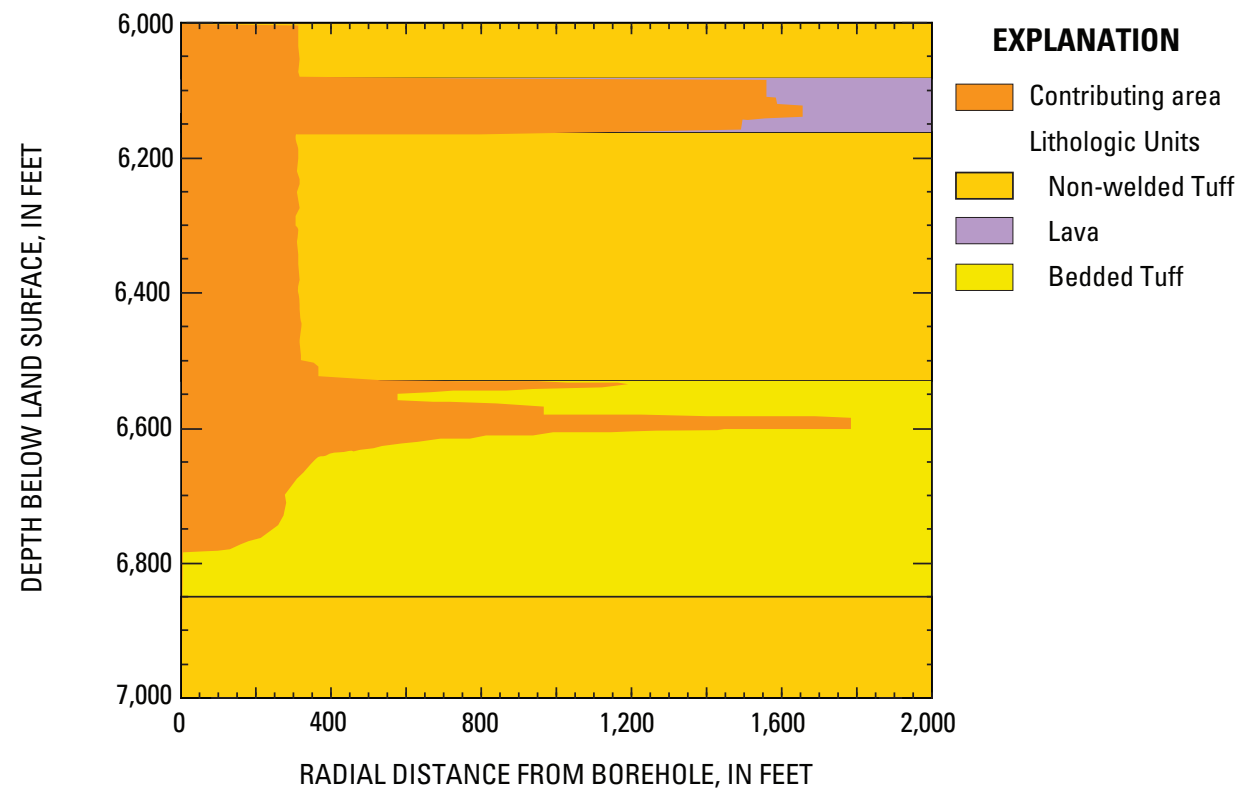

Figure 18. Area simulated as contributing flow to well ER-5-4-2 during flow logging, Frenchman Flat, Nevada. 


\section{Advantages of Integrated Approach}

Hydraulic-conductivity distributions interpreted with the integrated approach are improved from those computed by the proportional approach because many of the more complex well-aquifer system interactions introduced by an intricate well completion are simulated. Although transmissivity estimates can be preserved with both methods, only the integrated approach can reasonably and consistently extrapolate behind a cased section of borehole. The advantages of the integrated approach are quite relevant for many NTS wells that only partially penetrate aquifers, are completed with alternating screen and blank casing, have permeable gravel packs adjacent to blank casing, or have lengthy open annular spaces. All these completion practices introduce vertical flow components into the borehole, which cannot be interpreted correctly by proportional methods of flow-log analysis.

\section{Effects of Well Completion on Hydraulic- Conductivity Estimates}

The changes in wellbore flow often measured near joints between screens and blank casing are caused by convergent flow and must be interpreted using a more integrated approach. Groundwater flow is diverted toward the well screens in a partially penetrating well or in wells having completions with alternating screen and blank casing. Convergent flow into a screened interval destroys any proportionality between changes in wellbore flow and hydraulic conductivity. Any estimation of hydraulic conductivity for a unit that is not open to the borehole or is behind blank casing cannot be accomplished by direct interpretation.

Hydraulic conductivities estimated by proportional and integrated methods differ greatly in wells where the completion consists of alternating screen and blank casing. These differences are demonstrated by the results of the flow log analysis for the lava unit in the upper part of well ER-EC-1 (fig. 8). Hydraulic-conductivity estimates from the proportional method ranged between 0.03 and $200 \mathrm{ft} / \mathrm{d}$. Minimum values were coincident with blank casing and were estimated using equation 2. Hydraulic-conductivity estimates based on the integrated approach were less variable and ranged between 1 and $230 \mathrm{ft} / \mathrm{d}$. Extremes were computed from flow-log responses measured across screened intervals. Similar differences are demonstrated by the hydraulicconductivity distribution estimated for the trachytic lava penetrated by well ER-EC-4; except here, a greater fraction of the lava was behind blank casing, which forced more of the hydraulic-conductivity distribution to be based on extrapolation (fig. 12).

A lengthy open annular space behind blank casing greatly limits the ability of any method to accurately estimate hydraulic conductivity as is demonstrated by the results from well ER-5-4-2. Flow logs respond similarly to contributions from a permeable interval a few feet or hundreds of feet above or below a well screen. Multiple contributing intervals behind the blank casing also cause a similar response in the flow log. This response is defined by a sharp change at the joint between the screen and casing. A $200 \mathrm{ft}$ screen is set in a nearly 2,120-ft section of open borehole in well ER-5-4-2. About 70 percent of the flow entering the upper few feet of screen can be explained equally well with almost any hydraulic-conductivity distributions above the screened interval. The permeable lava unit $350 \mathrm{ft}$ above the screen is one of many examples that could explain the response based solely on regularization and a lack of lava or any other permeable unit directly adjacent to the screened interval (fig. 18).

\section{Lithology and Hydraulic Conductivity}

Hydraulic-conductivity distributions determined using the integrated approach are more clearly defined within a lithology than those determined from the proportional approach because the variation is minimized. Regularization enforces the assumption that hydraulic conductivities within a lithology are similar. The assumption that lithology is a predictor of hydraulic conductivity can be evaluated because estimated hydraulic conductivities bound the distribution in a lithology rather than allow a non-unique realization. Any meaningful evaluation of this assumption was limited to carbonate, lava, and trachytic lava lithologies where more than $100 \mathrm{ft}$ of screen or open hole was adjacent to a contiguous lithologic unit of more than a few hundred feet in thickness.

The representative thickness of carbonate rock (dolomite and vuggy dolomite) is $350 \mathrm{ft}$. This thickness is the thinnest interval tested where the standard deviation of hydraulic conductivity is at a minimum and was estimated by averaging hydraulic conductivities across successively thicker contiguous intervals, computing the multiplicative standard deviation of the averages, and identifying where the standard deviation of the averages ceases to decrease (fig. 19). The representative thickness for well ER-6-1-2 could be estimated because 1,300 ft of carbonate rocks are open to the wellbore (fig. 5). Results indicate that gross properties of the carbonate should be extrapolated and simulated with thicknesses of more than $350 \mathrm{ft}$.

The representative thicknesses of the lava in well ER-EC-1 and trachytic lava in well ER-EC-4 could not be determined, in part, because direct observations were limited by a complex well completion of alternating screens and blank casing. In all likelihood, the representative thickness of the lava and trachytic lava could have been estimated if the completion design included more lengthy and continuous screened sections across from the more than 250 - $\mathrm{ft}$ thick lavas in the boreholes. Results remain inconclusive because less than 40 percent of the units were screened and the continuous screen was limited to 30 -ft lengths. The representative thickness of the trachytic lava in well ER-EC-4 would constrain extrapolation to a larger area more so than in other lithologies because hydraulic-conductivity estimates span more than three orders of magnitude. 


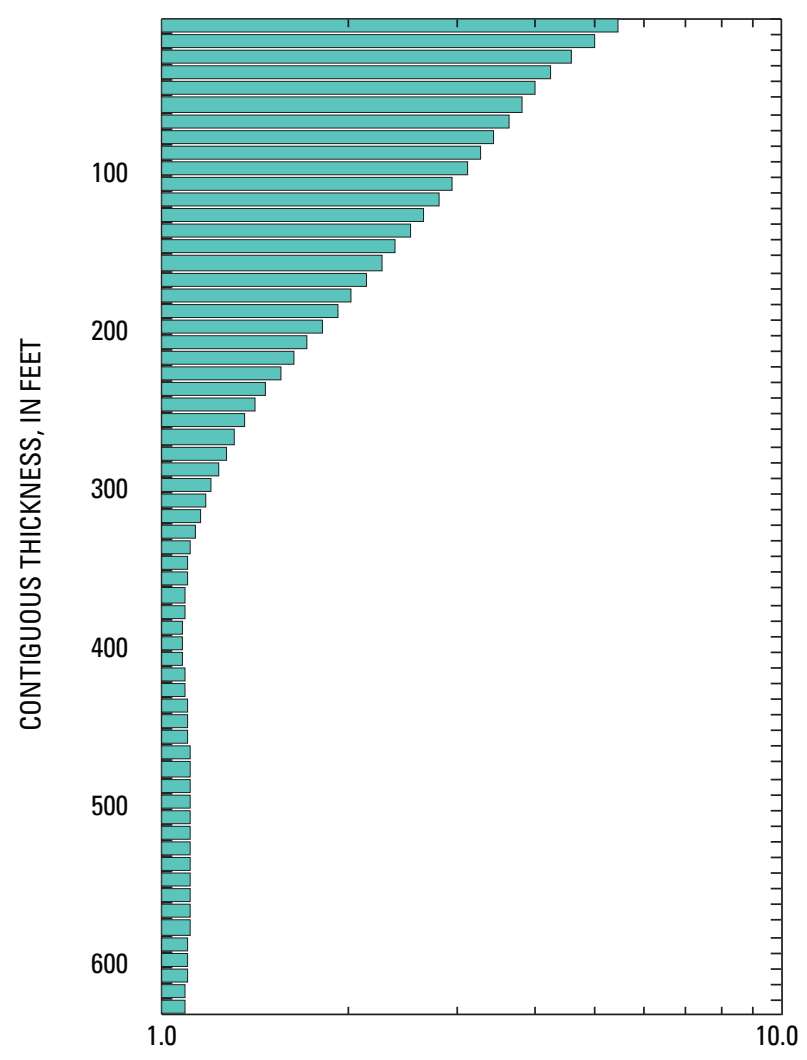

MULTIPLICATIVE STANDARD DEVIATION, IN FEET PER DAY

Figure 19. Multiplicative standard deviation of hydraulic conductivity in contiguous intervals of dolomite or vuggy dolomite that occurred in well ER-6-1-2, Yucca Flat, Nevada.

Hydraulic conductivities estimated behind blank casing should be excluded from any analysis of the variance within a lithology because these values are simply extrapolations of estimates made across from screened intervals. Hydraulic conductivities of intervals behind blank casing are estimated in the integrated approach in order to preserve the mean hydraulic conductivity. Estimated hydraulic conductivities remain close to the thickness weighted mean values because of regularization, which is indicated by the hydraulicconductivity distributions in the lava, well ER-EC-1 (fig. 8), and trachytic lava, well ER-EC-4 (fig. 12).

Hydraulic-conductivity distributions for tuff units could not be characterized because tuffs were split into six unique lithologies, all of which had generally low hydraulic conductivities. Subdividing the tuffs into multiple lithologies greatly limited the effect of any one lithology on a flow log. The sensitivity of velocity changes to a particular lithology was attenuated further by short intervals of alternating screen and blank casing adjacent to the tuff units. The hydraulic conductivity estimated for more than 90 percent of the tuff units was at the detection limit for flow logs and therefore could not be quantified relative to more permeable units.
Hydraulic conductivities of quartzite in ER-6-1-2 also were less than the detection limit of flow-log analysis which precluded estimating the variance in quartzite.

\section{Summary and Conclusions}

Hydraulic-conductivity distributions in four characterization wells on the Nevada Test Site were reinterpreted from flow-log and single-well aquifer test data using the well-bore analysis tool, AnalyzeHOLE. This tool uses a radial, axisymmetric flow model to simultaneously interpret measured flow-log and drawdown response and account for vertical flow components within the borehole and adjacent aquifer system. Vertical flow is an outcome of complex well completions, such as alternating sequences of screen and blank casing or lengthy annular openings or gravel packs across from blank casing, and highly heterogeneous aquifer systems. This analysis tool is well suited for interpreting flow logs measured in the deep and often complex characterization wells on the NTS because it not only considers vertical flow in the annular space and adjacent aquifer, but also minimizes hydraulic-conductivity variability within lithologic units.

Hydraulic-conductivity distributions are interpreted from flow logs at intervals of $10 \mathrm{ft}$ or more in thickness to reduce inherent noise. The hydraulic conductivity of the intervals used to vertically discretize the borehole and adjacent aquifer system is estimated with Parameter ESTimation (PEST) software. Regularization is used to extrapolate estimates to intervals behind cased sections of the borehole by minimizing the variability of hydraulic conductivity in a lithology and preserving the transmissivity of the aquifer system.

The four characterization wells analyzed (ER-6-12, ER-EC-1, ER-EC-4, and ER-5-4-2) are completed in carbonate and volcanic lithologic units. Borehole flow logs are generalized and interpreted at intervals of about $10 \mathrm{ft}$ or greater. Hydraulic-conductivity estimates vary by more than three orders of magnitude across a lithologic unit, indicating a high degree of heterogeneity in volcanic and carbonate-rock units. Analysis of carbonate rock, predominantly dolomite and vuggy dolomite in well ER-6-1-2, shows thick, lowpermeability sections (less than $10 \mathrm{ft} / \mathrm{d}$ ) contiguous with thin, highly permeable sections (greater than 1,000 ft/d). These results indicate a fracture-controlled hydraulic-conductivity distribution. Lava and trachytic lava units in wells ER-EC-1 and ER-EC-4, respectively, account for most (greater than 85 percent) of the measured borehole flow in volcanic rock. The large variance in the estimated hydraulic conductivity of lava and trachytic lava units represents intermingled high (greater than $50 \mathrm{ft} / \mathrm{d}$ ) and low (less than $1 \mathrm{ft} / \mathrm{d}$ ) flow zones behind screen and blank casing. Simulated minimum estimates of hydraulic conductivity are inexact and represent the lower detection limit of the method. 
Relations between lithology and hydraulic conductivity are relevant only where contiguous lithologic units are adjacent to screened or open-hole completions of $100 \mathrm{ft}$ or more. Dolomite, vuggy dolomite, lava, and trachytic lava are the most transmissive units with thickness weighted hydraulic conductivities ranging from 20 to $240 \mathrm{ft} / \mathrm{d}$. Hydraulicconductivity estimates across extensively screened tuff units were less than $1 \mathrm{ft} / \mathrm{d}$ on average and represent the detection limit of the method.

Interpretation of the representative thickness of a lithologic unit necessary to capture the variance in its hydraulic-conductivity distribution often is limited by overly complex well completions. A minimum representative thickness of $350 \mathrm{ft} / \mathrm{d}$ was estimated for carbonate rocks, where more than $1,300 \mathrm{ft}$ of contiguous dolomite is adjacent to the open-hole completion. Representative thickness estimates for volcanic rocks are inconclusive, however, because (1) direct observations are limited by well construction with alternating screen and blank casing, (2) the length of screened sections are limited to $30 \mathrm{ft}$, and (3) less than 40 percent of volcanic units analyzed are screened.

The uncertainty of hydraulic-conductivity estimates interpreted from flow logs can be reduced by completing wells with longer intervals of continuous screen and minimal gravel pack adjacent to blank casing. Longer intervals of continuous screens increase the total thickness where a change in the logged flow rate relates directly to a change in hydraulic conductivity. Filling annular spaces and minimizing the length of gravel pack adjacent to blank casing reduces potential contributions from permeable intervals through the annular space. Both measures decrease the need to extrapolate hydraulic conductivity, which increases confidence in the mean of the hydraulic-conductivity estimates interpreted for a given lithology.

Reinterpreted hydraulic-conductivity estimates using AnalyzeHOLE quantified and reduced uncertainty by generalizing flow logs prior to interpretation, considering potential flow contributions from cased intervals, and constraining variability within lithologic units. Improved hydraulic-conductivity estimates ultimately will lead to more accurate predictions of radionuclide transport. Results from this study also can be used to evaluate the value of analyzing flow logs to estimate hydraulic conductivity, direct future field activities, and promote an effective well-completion design.

\section{References Cited}

Bechtel Nevada, 2002, A hydrostratigraphic model and alternatives for the groundwater flow and contaminant transport model of Corrective Action Units 101 and 102Central and western Pahute Mesa, Nye County, Nevada: U.S. Department of Energy Report DOE/NV/11718-706, $383 \mathrm{p}$.
Bechtel Nevada, 2005, A hydrostratigraphic model and alternatives for the groundwater flow and contaminant transport model of Corrective Action Unit 97-Yucca FlatClimax Mine, Lincoln and Nye Counties, Nevada: U.S. Department of Energy Report DOE/NV/11718-1119, 288 p.

Blankennagel, R.K., and Weir, J.E., Jr., 1973, Geohydrology of the eastern part of Pahute Mesa, Nevada Test Site, Nye County, Nevada: U.S. Geological Survey Professional Paper 712-B, 35 p.

Bowman, G.K., Molz, F.J., and Boone, K.D., 1997, Borehole flowmeter application in fluvial sediments - Methodology, results, and assessment: Ground Water, v. 35, no. 3, p. 443-450.

Clemo, T., 2002, MODFLOW-2000 for cylindrical geometry with internal flow observations and improved water table simulation: Boise State University Technical Report BSU CGISS 02-01.

Cooper, H.H., and Jacob, C.E., 1946, A generalized graphical method for evaluating formation constants and summarizing well field history: American Geophysical Union Transactions, v. 27, p. 526-534.

Doherty, J., 2005, Manual for Version 10 of PEST: Brisbane, Australia, Watermark Numerical Computing.

Doherty, J., and Johnston, J.M., 2003, Methodologies for calibration and predictive analysis of a watershed model: Journal of the American Water Resources Association, v. 39, no. 2, p. 251-265.

Halford, K.J., 2000, Simulation and interpretation of borehole flowmeter results under laminar and turbulent flow conditions, in Seventh International Symposium on Logging for Minerals and Geotechnical Applications, 7th, Golden, Colorado, 2000, Proceedings: Houston, Tex., Society of Petrophysicists and Well Log Analysts, p. 157-168.

Halford, K.J, 2006, Documentation of a spreadsheet for timeseries analysis and drawdown estimation: U.S. Geological Survey Scientific Investigations Report 2006-5024, 40 p.

Halford, K.J., 2009, AnalyzeHOLE-An integrated wellbore flow analysis tool: U.S. Geological Survey Techniques and Methods 4-F2, 46 p.

Halford, K.J., Weight,W.D., and Schreiber, R.P., 2006, Interpretation of transmissivity estimates from single-well, pumping aquifer tests: Ground Water, v. 44, no. 3, p. $467-471$.

Halford, K.J., and Yobbi, D.K., 2006, Estimating hydraulic properties using a moving-model approach and multiple aquifer tests: Ground Water, v. 44, no. 2, p. 284-291. 
Harbaugh, A.W., Banta, E.R., Hill, M.C., and McDonald, M.G., 2000, MODFLOW-2000, the U.S. Geological Survey modular ground-water flow model-User guide to modularization concepts and the ground-water flow process: U.S. Geological Survey Open-File Report 00-92, 121 p.

Javandel, I., and Witherspoon, P.A., 1969, A method of analyzing transient fluid flow in multilayered aquifer: Water Resources Research, v. 5, no. 4, p. 856-869.

Keys, S.W., 1990, Borehole geophysics applied to groundwater investigations: U.S. Geological Survey Techniques of Water Resources Investigations, book 2, chap. E2, 150 p.

Laczniak, R.J., Cole, J.C., Sawyer, D.A., and Trudea, D.A., 1996, Summary of hydrogeologic controls on groundwater flow at the Nevada Test Site, Nye County, Nevada: U.S. Geological Survey Water-Resources Investigations Report 96-4109, 59 p.

Langevin, C.D., 2008, Modeling axisymmetric flow and transport: Ground Water, v. 46, no. 4, p. 579-590.

Mankinen, E.A., Hildenbrand, T.G., Dixon, G.L., McKee, E.H., Fridrich, C.J., and Laczniak, R.L., 1999, Gravity and magnetic study of the Pahute Mesa and Oasis Valley Region, Nye County, Nevada: U.S. Geological Survey Open-File Report 99-303, 58 p.

McDonald, M.G., and Harbaugh, A.W., 1988, A modular three-dimensional finite-difference ground-water flow model: U.S. Geological Survey Techniques of Water-Resources Investigations, book 6, chap. A1, 576 p.

Molz, F.J., Morin, R.H., Hess, A.E., Melville, J.G., and Güven, O.,1989, The impeller meter for measuring aquifer permeability variations - Evaluations and comparison with other tests: Water Resources Research, v. 25, p. 1677-1683.

Moreo, M.T., Halford, K.J., La Camera, R.J., and Laczniak, R.J., 2003, Estimated ground-water withdrawals from the Death Valley Regional Flow System, Nevada and California, 1913-98: U.S. Geological Survey Water-Resources Investigations Report 03-4245, 28 p.

Oberlander, P.L., Lyles, B.F., and Russell, C.E., 2002, Borehole testing and characterization of Western Pahute Mesa-Oasis Valley ER-EC wells: Desert Research Institute Publication 45194, 56 p.

Oberlander, P.L., and Russell, C.E., 2003, Depth-specific hydraulic testing of Yucca Flat and Frenchman Flat environmental restoration wells: Desert Research Institute Publication 45199, 22 p.
Paillet, F.L., 1998, Flow modeling and permeability estimation using borehole flow logs in heterogeneous fractured formations: Water Resources Research, v. 34, no. 5, p. 997-1010.

Reilly, T.E., and Harbaugh, A.W., 1993, Simulation of cylindrical flow to a well using the U.S. Geological Survey modular finite-difference ground-water flow model: Ground Water, v. 31, no. 3, p. 489-494.

Sweetkind, D.S., Belcher, W.R., Faunt, C.C., and Potter, C.J., 2004, Geology and hydrology, in Belcher, W.R., ed., chap. B of Death Valley regional ground-water flow system, Nevada and California-Hydrogeologic framework and transient ground-water flow model: U.S. Geological Survey Scientific Investigations Report 2004-5205, p. 27-98.

Theis, C.V., 1935, The relation between the lowering of the piezometric surface and the rate and duration of discharge of a well using ground water storage: American Geophysical Union Transactions, v. 16, p. 519-524.

U.S. Department of Energy, 2000a, Completion report for ER-EC-1: U.S. Department of Energy Nevada Environmental Restoration Project DOE/NV_-11718-381, $115 \mathrm{p}$.

U.S. Department of Energy, 2000b, Completion report for ER-EC-4: U.S. Department of Energy Nevada Environmental Restoration Project DOE/NV_-11718-397, 122 p.

U.S. Department of Energy, 2004, Completion report for well cluster ER-6-1: U.S. Department of Energy Nevada Environmental Restoration Project DOE/NV_-11718-862, 144 p.

U.S. Department of Energy, 2005, Completion report for well cluster ER-5-4: U.S. Department of Energy Nevada Environmental Restoration Project DOE/NV_-11718-998, 159 p.

Winograd, I.J., and Thordarson, W., 1975, Hydrogeologic and hydrochemical framework, south-central Great Basin, Nevada-California, with special reference to the Nevada Test Site: U.S. Geological Survey Professional Paper 712-C, 126 p. 


\section{Appendix A. Flow-Log Database for the Nevada Test Site, Nye County, Nevada}

A multi-component database was developed to store and analyze flow-log data from 18 boreholes at the Nevada Test Site. The Microsoft ${ }^{\circ}$ Access database (available at http://pubs.usgs.gov/sir/2010/5004) consists of six tables listed in table A1 that document the well site, construction and lithology data, flow and electric logs, and the water-level and aquifer-test data collected at each well. Well information, construction, and lithology data are compiled from drillers' logs, well completion reports, and other published and unpublished information. Flow and electric logs, and water-level and aquifer-test data are taken from Microsoft@ Excel tables provided by the Desert Research Institute (DRI). The tabular attributes of each table are described in four associated look-up tables (table A2).

Table A1. Description of tables contained in the flow-log database for the Nevada Test Site, Nye County, Nevada.

\begin{tabular}{|c|c|c|c|}
\hline Table name & Table grouping & Description & Remarks \\
\hline tbl_WellConst & Well-construction information & $\begin{array}{l}\text { Hole and casing diameters, intervals, and } \\
\text { construction type. }\end{array}$ & $\begin{array}{l}\text { May have multiple entries for each site } \\
\text { that describe intervals of hole. }\end{array}$ \\
\hline tbl_WellLith & Lithology information & $\begin{array}{l}\text { Stratigraphic and lithologic units } \\
\text { and lithology; hydrographic and } \\
\text { hydrostratigraphic units where } \\
\text { available. }\end{array}$ & $\begin{array}{l}\text { Descriptions provided are original } \\
\text { descriptions written by many } \\
\text { geologists and workers and compiled } \\
\text { primarily by D.B. Wood of the U.S. } \\
\text { Geological Survey. }\end{array}$ \\
\hline tbl_FlowLogs & Flow log information & $\begin{array}{l}\text { Date, log identification, depth, flow-log } \\
\text { rate, line speed, temperature, pumping } \\
\text { rate, AvgF, change in temperature, and } \\
\text { tension. }\end{array}$ & $\begin{array}{l}\text { Log identification is based on average } \\
\text { pumping rate and line speed during } \\
\text { flow logging. }\end{array}$ \\
\hline tbl_ElecLogs & Electric log information & Date, log type, depth, value. & $\begin{array}{l}\text { Log types include electric conductivity, } \\
\text { pH, and temperature. }\end{array}$ \\
\hline
\end{tabular}

Table A2. Description of look-up tables contained in the flow-log database for the Nevada Test Site, Nye County, Nevada.

\begin{tabular}{|c|c|c|}
\hline Look-up table name & Table grouping & Description \\
\hline tbl_lut_ConstType & Well-construction information. & Defines the type of well construction (annulus or borehole). \\
\hline tbl_lut_HUtoHSU & Lithology information. & $\begin{array}{l}\text { Links each hydrographic unit (HU) to a specific } \\
\text { hydrostratigraphic unit (HSU) and includes } \\
\text { descriptions and abbreviations. }\end{array}$ \\
\hline tbl_lut_Aqtst & Water-level and aquifer test information. & Defines the code used for the AqTest field. \\
\hline tbl_lut_LogType & Electric log information. & $\begin{array}{l}\text { Defines the abbreviation listed for electric log type and } \\
\text { associated units. }\end{array}$ \\
\hline
\end{tabular}




\section{Appendix B. Input Files for AnalyzeHOLE Simulations}

AnalyzeHOLE simulations are summarized for wells ER-6-1-2, ER-EC-1, ER-EC-4, and ER-5-4-2 in four AnalyzeHOLE data (*.AHD) files. The AHD format is Microsoft ${ }^{\circledR}$ Excel 97-2003 Workbook (*.xls) with the extension changed from XLS to AHD (Halford, 2009).

The AnalyzeHOLE data files contain all lithology, hydraulic properties, well construction, raw flow log, depth-dependent flow observations, and measured drawdowns in the pumping well. Model discretization, dimensions, and period of analysis also are defined. Depth-dependent hydraulic conductivity estimates of the aquifer system and annular fill are simulation results that are stored in the AHD files.

Input files for AnalyzeHOLE can be accessed and downloaded at URL http://pubs.usgs.gov/sir/2010/5004. 
Publishing support provided by the U.S. Geological Survey

Publishing Network, Tacoma Publishing Service Center

For more information concerning the research in this report, contact the Director, Nevada Water Science Center

U.S. Geological Survey

2370 N. Deer Run Road

Carson City, Nevada 89701

http://nevada.usgs.gov 


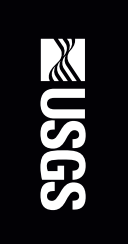

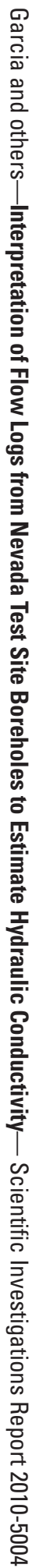

